\title{
Intergenerational Transfers and the Stability of the Swiss Retirement System
}

\author{
Martin Eling \\ Institute of Insurance Economics, University of St.Gallen, Kirchlistrasse 2, St. Gallen 9010, Switzerland. \\ E-mail: martin.eling@unisg.ch
}

We analyse intended and unintended solidarity transfers between the young and the old in the Swiss retirement system. In addition to the intended solidarity transfers in the pay-as-you-go system, we identify a systematic unintended solidarity transfer from the active population to new retirees in the occupational pension system, which occurs due to the statutory conversion rates not being actuarially fair. After providing an overview of intergenerational transfers in Switzerland, we briefly review the Swiss retirement system. Then, we quantify the unintended transfer in the occupational pension system and finish by discussing several policy measures that could be implemented to avoid this intergenerational transfer. The unintended solidarity transfer casts some doubt on the financial stability and social acceptability of the Swiss retirement system, which is often considered one of the best in the world. As such, the problems of and recommendations for the Swiss system are of interest to other pension systems as well.

The Geneva Papers (2013) 38, 701-728. doi:10.1057/gpp.2013.28

Keywords: intergenerational risk sharing; Switzerland; retirement; occupation pension provisions

Article submitted 15 January 2013; accepted 24 July 2013; published online October 2013

\section{Introduction}

This paper analyses intergenerational transfers in and the financial sustainability of the Swiss retirement system. Switzerland is an interesting case because its legal requirements result in both intended and unintended solidarity transfers between younger and older generations. The latter could be viewed as an unfair intergenerational transfer that casts doubt on the financial stability and social acceptance of the country's retirement system.

Demographic change poses major challenges for all industrialised countries, especially with respect to their retirement systems, ${ }^{1}$ and Switzerland is no exception. According to the $\mathrm{OECD},{ }^{2}$ Switzerland has the second highest life expectancy in the world. However, its statutory retirement age is far lower than in many other OECD countries, some of which have already implemented a pension-eligible age of 67 or older. ${ }^{3}$

\footnotetext{
${ }^{1}$ According to the World Economic Forum (2008), the ageing of the world population is one of the biggest challenges facing the social security systems in both developed and less developed countries.

2 OECD (2012a).

${ }^{3}$ Twelve countries now mandate a retirement age of 67 or more: the United States, the United Kingdom, Germany, Norway, Denmark, Iceland, Italy, Poland, Australia, the Netherlands, Ireland and Israel. Other countries are in the process of increasing their retirement age. The European Commission recommends 70 as retirement age. See European Commission (2012). In Switzerland, the retirement age for women is 64 and for men 65.
} 
Table 1 Transfers between the young and the old in Swiss society

\begin{tabular}{ll}
\hline Transfers at the government level & Transfers in the private sector \\
\hline - Taxes and fees & - Inheritances \\
- Social security (e.g. retirement, health care) & - Voluntary work (including childcare and elderly care) \\
- Subsidies (e.g. nursery school) & - Price reductions in social and cultural fields \\
- Education & - Environmental impact (climate change, nuclear waste) \\
- Infrastructure & \\
- Public debt & \\
\hline
\end{tabular}

The intergenerational contract and, consequently, fairness between generations are key components of society. Rarely is either consciously recognised and they are difficult to put into words, but they are deeply rooted in society, creating a basic understanding that is accepted by both the young and the old. In general, intergenerational fairness is achieved when the chances of future generations are at least as great as those of the current generation. ${ }^{4}$ The enormous social importance of the intergenerational contract in Switzerland is evidenced by the fact that responsibility towards future generations is defined in the preamble of the federal constitution of the Swiss Confederation. ${ }^{5}$ In this paper we argue that the Swiss retirement system violates this intergenerational contract.

The intergenerational contract involves solidarity transfers between young and old people not only in the retirement system, but in many areas of society, both public and private. The left-hand side of Table 1 shows transfers at the government level that involve income (e.g. taxes and fees, social security contributions, new debt) and expenditures (e.g. social security expenditures, subsidies, education, infrastructure). On the right-hand side of the table, we show transfers that occur in the private sector: inheritances, voluntary work, price reductions in social and cultural fields, and the increasingly adverse environmental impact on future generations caused mainly by the private sector.

Generally, the transfer is from the young working population to the retired population. However, the intergenerational contract is not a one-way street: older people can make important contributions to the lives of young people, for example, by voluntary work. Eling ${ }^{6}$ studies intergenerational transfers in Switzerland and concludes that there are areas where the intergenerational contract works well ${ }^{7}$ and others where it does not. ${ }^{8}$

\footnotetext{
${ }^{4}$ See Tremmel (2003).

5 The preamble states "im Bewusstsein der gemeinsamen Errungenschaften und der Verantwortung gegenüber den künftigen Generationen" (aware of the common achievements and acting responsibly towards future generations).

${ }^{6}$ Eling (2012).

${ }^{7}$ For example, Switzerland was one of the first countries to put a brake on public debt, which has effectively limited new debt over the last years (see, e.g. Feld and Schaltegger, 2011). In the field of infrastructure, Switzerland invests more than other countries (see OECD, 2012b). Moreover, the vast amount of voluntary work done in Switzerland illustrates the country's long tradition of social solidarity (see Schön-Bühlmann, 2011).

${ }^{8}$ Eling (2012) discusses the increasing pressure on the young generation in the retirement, health, casualty and other social security systems. It is also shown that in regard to inheritances, transfers from old to young are not very substantial, since almost two-thirds of the heirs are older than 55 (Stutz et al., 2007) and investments in
} 
Although the Swiss retirement system is often declared to be one of the best in the world, ${ }^{9}$ a critical review of it reveals systematic, unfair intergenerational transfers between the young and the old. The statutory conversion rate in the mandatory occupational pension system is much higher than fair conversion rates, meaning that the pension paid to new retirees is higher than their accrued assets. Since a pension fund is a closed institution with active and retired members, this results in unintended money transfers from the active working population to the retiring population. We critically review this transfer, since we believe that the problems and challenges of the Swiss system can have important lessons for other retirement systems in the world.

Therefore, this paper analyses intergenerational transfers in the Swiss retirement system. We forecast the financial stability of the mandatory occupational pension system and document the deficits arising from the statutory conversion rate. ${ }^{10} \mathrm{We}$ interpret these deficits as a violation of intergenerational fairness and outline policy measures to avoid them. In our discussion of reforms, we review the systems of other European countries, such as the indexation of retirement age in Denmark, the piecewise increase of retirement age in the United Kingdom and the sustainability factor in the German retirement system, a discussion that may be insightful for other pension systems as well. ${ }^{11}$

The remainder of the paper is organised as follows. In the next section we briefly review the Swiss retirement system and its main elements. We describe our model for projecting future financial deficits arising from the statutory conversion rate in the subsequent section and illustrate the main results and sensitivity tests in the latter section. We outline how policy could be designed to avoid the unfair intergenerational transfer in the fifth section and explain two limitations of the analysis in the penultimate section. Finally, we conclude in the last section.

\section{The Swiss retirement system}

The Swiss retirement system is predefined by the government and provided by both public and private institutions. It consists of three pillars: a first pillar, which is organised as a

education and families are relatively low (OECD, 2012c; Bühlmann et al., 2012). Eling (2012) concludes that the intergenerational contract does not work very well in Switzerland. We build upon and extend Eling's (2012) results with a detailed analysis of intergenerational transfers in the retirement system.

${ }^{9}$ Many international studies conclude that the Swiss three-pillar model is among the best retirement systems in the world, for example, the OECD, the World Bank and other international organisations. See, for example, Baumann et al. (2011) and Australian Centre for Financial Studies (2011).

${ }^{10}$ A limitation of the analysis is that we implicitly assume that individual behaviour is independent from the retirement setting and thus fixed over time. Economic literature shows that this assumption does not hold in the "real" world. See, for example, Stock and Wise (1990), Gruber and Wise (2004), Samwick (1998), and Hanel and Riphahn (2012). Another limitation is that we only analyse redistribution effects arising from the high conversion rate in the mandatory occupational pension system. Other elements of the system (benefits for surviving dependents and in case of invalidity) and resulting cross-subsidisations between young and old people are not taken into account.

${ }^{11}$ In this work, we focus on the intergenerational transfer and do not discuss social transfers between the poor and the rich. Redistribution between young and old should result in a smoothing of lifetime income, whereas social transfers between poor and rich should achieve more equality in society. For a detailed analysis including both components, see Engler (2011). 
Table 2 Pay-as-you-go vs capital-funded retirement systems

\begin{tabular}{|c|c|}
\hline Pay-as-you-go (first pillar) & Capital-funded (second and third pillars) \\
\hline Vulnerable to changes in demography & Less vulnerable to changes in demography \\
\hline Less vulnerable to changes in capital markets & Vulnerable to changes in capital markets \\
\hline $\begin{array}{l}\text { Intergenerational transfer/solidarity between } \\
\text { young and old is the foundation of the system }\end{array}$ & $\begin{array}{l}\text { Intergenerational transfer/solidarity is not part of the system } \\
\text { However: transfer from the active to new retirees (in the } \\
\text { mandatory part of the second pillar), since statutory } \\
\text { conversion rates are too high, results in unfair transfers }\end{array}$ \\
\hline $\begin{array}{l}\text { Financial deficits for the first pillar are projected } \\
\text { by the Federal Social Insurance Office (see } \\
\text { BSV, 2012a) }\end{array}$ & $\begin{array}{l}\text { New analysis done in this paper: for the second pillar we } \\
\text { provide a projection based on the gap between statutory } \\
\text { conversion rates and fair conversion rates }{ }^{\mathrm{a}}\end{array}$ \\
\hline
\end{tabular}

${ }^{\mathrm{a}}$ As the third pillar is purely on an individual basis, we do not need to analyse it in the context of intergenerational transfers and thus it is not discussed in this paper.

pay-as-you-go system by the Federal Social Insurance Office (Bundesamt für Sozialversicherung); a second pillar consisting of occupational pension plans organised as a capital-funded system by public and private pension funds; and a third pillar that consists of tax-subsidised individual provisions, which are also capital funded and organised by the private sector within predefined rules. It is generally conceded that Switzerland has a very good retirement system, since it is a combination of pay-as-you-go and capital-funded elements (see Table 2), making it more diversified than other retirement systems that rely on only one of these two elements. ${ }^{12}$

Nevertheless, the Swiss retirement system is severely affected by demographic change. The first pillar is vulnerable to demographic change, just like any other pay-as-you-go system. What is surprising is that the second pillar is also affected by demographic change due to excessive statutory conversion rates for the mandatory occupational pension plan as compared with actuarially fair ones.

In Switzerland, an occupational pension plan is mandatory for workers earning a wage of up to CHF 83,520 per year. For the mandatory occupational pension plan, the government sets the conversion rate at which the accumulated assets are converted into a pension. The statutory conversion rate was 6.90 per cent for men and 6.85 per cent for women in 2012 - values far above actuarially fair conversion rates. ${ }^{13}$ Thus, although the

12 The target of the first and second pillars is a pension that is 60 per cent of the last income. For low-income employees, the majority of the pension comes from the first pillar; for high-income employees, a higher fraction of the pension comes from the second pillar. On average, 40 per cent of the pension comes from the first pillar and 60 per cent from the second and third pillars. See Bütler and Jäger (2007). It is also important to mention that only parts of the premium paid in the second pillar are used to finance the pension. There are additional benefits for surviving dependents and in case of invalidity which are financed by a risk premium. Moreover, the insurer can charge a separate cost premium to cover administrative costs. We thus distinguish the risk premium (to finance the risk of early death and invalidity), the savings premium (to finance the pension) and the cost premium (to cover the administrative costs). The Swiss pension system is unlike the U.S. 401(k) system in that the purchase of an annuity is not a separate, unbundled contract.

${ }^{13}$ From 2014 onwards, the rate will be 6.80 per cent for both men and women. For income above CHF 83,520 per year, it is possible to opt for additional savings in the non-mandatory part of the second pillar. Pension funds are forced to offer the conditions set by the government for the mandatory occupational plans, while for the 


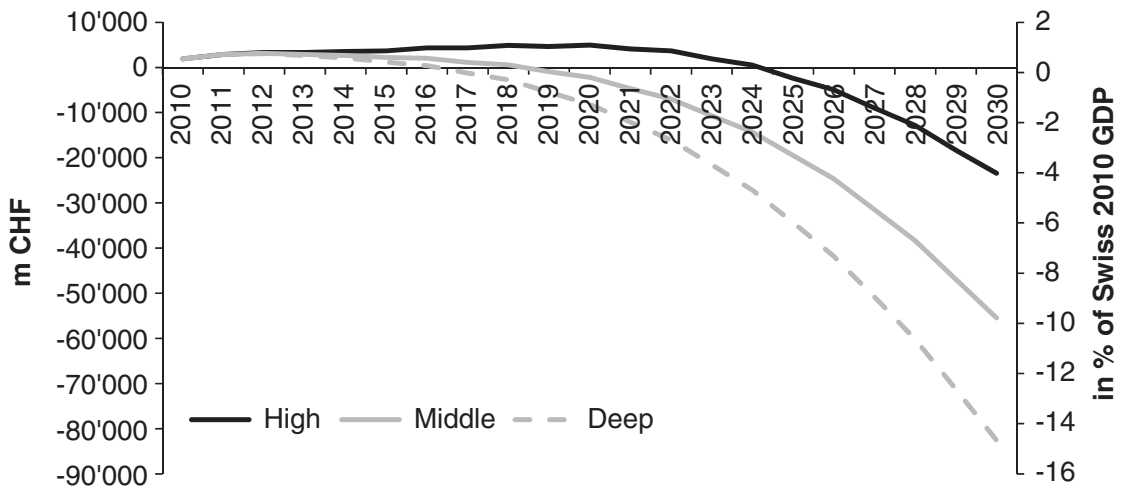

Figure 1. Financial development of the first pillar (AHV; data source: BSV, 2012a).

capital-funded system has no connection with solidarity, legal regulations lead to redistribution from the active population to new retirees. ${ }^{14} \mathrm{We}$ discuss these transfers in more detail below.

For financial development of the first pillar of the Swiss retirement system (the AHV) over time, we rely on existing annual projections provided by the Federal Social Insurance Office. ${ }^{15}$ As for other pay-as-you-go systems, these analyses show that the contributions paid by the working population are no longer sufficient to fund retirees' pensions, since the old-age dependency ratio will dramatically increase over the next 20 years. Figure 1 shows the financial development of the first pillar for the so-called deep, middle and high scenarios ${ }^{16}$; we show the cumulative result of income minus expenditure (excluding the AHV fund), ${ }^{17}$ that is, the annual results are cumulated. The figure shows that for the middle scenario, the AHV is stable until 2018 and then generates

non-mandatory occupational plans other conditions can apply. This leads to the situation where an extremely high conversion rate is offered in the mandatory plans, and a much lower rate is available in the non-mandatory plans. For example, the Swiss national railway SBB offers 5.8 per cent for the non-mandatory plans, which is close to the fair conversion rate according to our calculations. New retirees in Switzerland can then choose between the annuity and the capital option. However, given the excessively favourable conditions for annuitisation, almost everyone chooses the annuity. See BSV (2013, p. 11). Early and late retirement are also possible, with adjustments to the pensions. Moreover, it is also possible to claim the public pension at 65 and continue working. See OECD (2011) for more details.

${ }^{14}$ For a detailed description of the system, see Bütler (2002), Dorn and Sousa-Poza (2003), Bütler (2009), and Braun et al. (2011).

15 BSV (2012a).

16 The Federal Office of Statistics (2010) estimates three main scenarios. The "deep" one is characterised by a declining birth rate, a constant life expectancy and a stagnant population. The "high" scenario involves a higher birth rate, longer life expectancy and a growing population. The "middle" scenario is an average of these two extremes, which can thus be considered as a best estimate. We consider all three scenarios in our sensitivity tests (section "Main results and sensitivity tests").

17 The AHV fund is an additional fund for financing the first pillar. It amounted to CHF 41.1 billion at the end of 2011 (see Ausgleichsfonds, 2012). According to the projections of the Federal Social Insurance Office, this fund will become negative in 2028. See BSV (2012a). 
706

massive financial deficits. Up to the year 2030, the cumulated deficit amounts to CHF 55 billion in this setting. ${ }^{18}$

There are no annual projections for the second pillar comparable to those presented in Figure 1. Selected numbers for a few years are presented in EDI ${ }^{19}$ and Credit Suisse. ${ }^{20}$ EDI $^{19}$ discusses financial losses arising from the high statutory conversion rate and estimates an annual loss of CHF 600 million for the years 2011 and 2016. Credit Suisse ${ }^{20}$ estimates a redistribution of CHF 1 billion as early as 2011. In the following, we project the transfer from the active population to the newly retired that occurs due to the excessive legal conversion rate as compared to the fair conversion rate. ${ }^{21}$

\section{Modelling the intergenerational transfer from the high statutory conversion rate in the mandatory part of the second pillar}

To project the transfers from the active population to the newly retired, we need three models. The first model projects the number of new retirees in the occupational pension system, the second model projects the respective average assets at the point of retirement, and the third model projects the actuarially fair conversion rate, making certain assumptions as to interest rate and life expectancy. Assumptions about interest rate, demographic change and economic development are varied in sensitivity tests so as to analyse the robustness of the outcomes. Below, we briefly describe each model.

- Model 1: The number of new retirees in the occupational pension system is estimated using data from the Federal Statistical Office. We start with the number of retired persons today and then project this number based on the middle scenario of the Federal Statistical Office. $^{22}$ In our projection, the number of new pensioners increases from 40,715 in 2010 to 57,049 in 2030 . In sensitivity tests, three different scenarios for demographic development are considered. ${ }^{13}$

- Model 2: We project the average assets in the mandatory part of the occupational pension plan and set these to CHF 200,000 in 2012. ${ }^{19}$ Our projection of average retirement assets is

${ }^{18}$ It should be noted that the actual development of the AHV has been better than projected by older scenario analyses. See, for example, BSV (2006). The reason is the good economic development and the massive immigration of highly qualified young employees over the last several years. Economic development and the migration of young foreigners, however, cannot overcome the adverse development shown in Figure 1, especially since the baby boomer generation will retire in the next years. A comparison of older projections with actual outcomes for the second pillar is not possible, since we cannot compare projections with actual observations (as we can for the AHV).

${ }^{19}$ EDI (2011).

${ }^{20}$ Credit Suisse (2012)

${ }^{21}$ Note that the occupational pension system currently already has a financial deficit of 41.8 billion CHF. In addition to being due to the problematic transfers described in this paper, these deficits are also due to bad capital market development. See BSV (2012b).

22 The number of new retirees in year $x\left(N R_{x}\right)$ is calculated as $P R_{x} / P R_{x-1} \times N R_{x-1}$, with $P R_{x}$ as potential retirees in year $x$ according to the demographic projections of the Federal Statistical Office. Separate calculations for men and women are made. Table A1 in the Appendix shows the development of the number of new retirees up to 2030 according to this projection. 
based on existing projections of maximum possible assets in the mandatory part. ${ }^{23} \mathrm{We}$ take into account that the mandatory occupational system in Switzerland is still in the construction phase, that is, the average assets at retirement will increase disproportionately up to 2024 for women and to 2025 for men since the system was made mandatory in 1985 (people start making payments into the occupational pension plan at age 25). In our projection, the average assets at retirement increase from CHF 200,000 in 2012 to about CHF 310,000 in 2030.

- Model 3: We compare the statutory conversion rate with the actuarially fair conversion rate. The actuarially fair conversion rate is calculated as the reciprocal of the annuity factor, taking into account widows and orphans pensions provided by the system. The fair conversion rate is driven by assumptions on contingent life expectancy at retirement and the interest rate. We determine the conversion rates using the VZ 2010 tables, which are published by the pension fund of the city of Zurich based on its tracking of 21 public service employer pension funds. These tables are frequently employed for this purpose and also considered in EDI. ${ }^{19,24}$ For the interest rate, we use a baseline scenario of 3.5 per cent and vary it between 1.5 and 4.5 per cent. ${ }^{25}$ For an interest rate of 3.5 per cent, the fair conversion rate in the year 2012 is 5.75 per cent for men aged 65. In 2030, it would be 5.52 per cent. For women aged 64, the fair conversion rate is 5.75 per cent in 2012 and 5.54 per cent in 2030. The decrease in the conversion rate reflects the increase in life expectancy. In 2012, the statutory conversion rate is 6.90 per cent for men and 6.85 per cent for women; from 2014 onward, it will be 6.80 per cent for both men and women.

Based on these three models, the transfer effect of the high statutory conversion rate from the active population to new retirees can be calculated. We follow $\mathrm{EDI}^{19}$ and Credit Suisse ${ }^{20}$ and estimate the transfer volumes per year from the active population to new retirees as:

$$
\text { Transfer of newly retired }=\text { average assets } \cdot\left(\frac{\text { statutory conversion rate }}{\text { fair conversion rate }}-1\right)
$$

- Number of newly retired

${ }^{23}$ The average assets at retirement in year $x\left(R A_{x}\right)$ are calculated as $200,000 / \max R A_{2012} \times \max R A_{x}$, with $\max R A_{x}=\max R A_{x-1} \times(1+\mathrm{BVG}$ min interest rate $)+\max$ coordinated wage $x_{x} *$ retirement credits. The maximum assets at retirement in year $2012\left(\max R A_{2012}\right.$ ) are CHF 276,686 for men and CHF 288,171 for women. See BSV (2011). The estimated average assets at retirement from EDI (2011) are CHF 200,000. Table A2 in the Appendix shows the development of the maximum and average assets at retirement.

${ }^{24} \mathrm{We}$ consider tables for generations (Generationentafeln), that is, we take increasing life expectancy into account in our projections. For widows and orphans pensions, we continue the current situation of 60 per cent pension for widows and 20 per cent for orphans. Note that the life expectancy of pensioners in the occupational pension system tends to be higher than that of the average pensioner, which is why it is important in this case to use the more specific VZ 2010 projections and not the projections from the Federal Statistical Office. Calculation of the conversion rate is based on the classical annuity factor, but is made more complicated due to the widows and orphans pensions. The projections used in this paper are shown in Table 9.

${ }^{25}$ The value of 3.5 per cent is the current reference interest rate in the FRP 4 directive. This directive is a nonbinding recommendation with respect to the technical interest rate for assessing pension liabilities and technical provisions developed by the Swiss Chamber of Pension experts. See www.technischerzinssatz.ch. Note that the rate of 3.5 per cent in the baseline scenario is already a relatively optimistic estimate for the technical interest rate. For example, the FRP 4 forecasts a significant reduction in the technical interest rate in the coming years. Accordingly, it is important to test alternative interest rate scenarios, which we do in this section. 


\section{Main results and sensitivity tests}

\section{Main results}

Table 3 shows the results of the transfer analysis for the baseline scenario, assuming an interest rate of 3.5 per cent and using the middle scenario of the Federal Statistical Office. We show the number of newly retired from Model 1, their average assets from Model 2, the fair conversion rate from Model 3, the statutory conversion rate and the resulting transfer from the active population to the newly retired.

Table 3 shows that, as early as the year 2010, there is a transfer of CHF 1.6 billion from the active population to the 29,325 men and 11,390 women who retire. ${ }^{26}$ A single male retiring in the year 2010 receives a pension that is CHF 39,288 higher than what he would be entitled to under actuarially fair conditions. ${ }^{27}$ Accordingly, the pension is only 82.5 per cent funded $(185,398 /(185,398+39,288))$, that is, only 82.5 per cent of the pension can be financed with the accumulated assets. In 2030, CHF 73,429 too much is granted to a single retired male and the pension is only 81.1 per cent financed by accumulated assets.

It is important to remember in interpreting the redistribution results that it is permissible to apply lower conversion rates to the non-mandatory part of the occupational provision. This can result in the actual conversion rate applied being lower than the statutory minimum conversion rate. Accordingly, the non-mandatory pensions receive fewer transfers from the young than do the mandatory pensions. Credit Suisse ${ }^{20}$ and Aon Hewitt ${ }^{28}$ show, however, that the applied real conversion rates are barely below the minimum conversion rates. $^{29}$

In Figure 2 we compare our projections for the occupational pension system with the existing projections for the pay-as-you-go system AHV. ${ }^{15}$ We show the cumulative deficit for the two systems, that is, we summed the annual results. For the AHV, the numbers from Figure 1 are cumulated (middle scenario); for the occupational pension system, the numbers from Table 3 are cumulated.

Figure 2 shows large future financial deficits for both the first and second pillars of the Swiss retirement system. The AHV is stable for a few years, but the occupational pension system has structural deficits every year. The AHV balance will continue to be positive until 2018, but then will reverse drastically. In the year 2030, the cumulated funding gap in the first pillar is CHF 55.5 billion and another CHF 54.8 billion for the occupational pensions. This results in a financial deficit of CHF 110.2 billion, which ultimately must be

\footnotetext{
${ }^{26}$ Our redistribution volume for 2010 is higher than that in EDI (2011). The reason is that the conversion rate of 6.4 per cent considered by EDI (2011) requires a much higher interest rate than the one used here (3.5 per cent); indeed, an interest rate of 4.35 per cent is required (see EDI, 2011, p. 83), which is relatively high considering the current low-interest environment.

${ }^{27}$ This can be calculated as $185,398 *(7.0$ per cent $/ 5.776$ per cent -1$)$.

28 Aon Hewitt (2011).

29 The real applied conversion rates are 6.80 per cent in Credit Suisse (2012) and 6.68 per cent in Aon Hewitt (2011). Since the real conversion rate applied is on average still very close to 6.8 per cent, the reduction in transfers is not very substantial. However, it can be assumed that the real conversion rates applied will decrease in the coming years in light of the increasing life expectancy and the difficult financial situation of the pension funds.
} 
Table 3 Results for the baseline scenario (fair conversion rate with 3.5 per cent interest rate, middle scenario of Federal Statistical Office)

\begin{tabular}{|c|c|c|c|c|c|c|c|c|c|c|c|}
\hline \multirow[t]{2}{*}{ Year } & \multicolumn{2}{|c|}{ No. new retirees } & \multicolumn{2}{|c|}{ Average assets (CHF) } & \multicolumn{2}{|c|}{ Fair conversion rate } & \multicolumn{2}{|c|}{ Statutory conv. rate } & \multicolumn{3}{|c|}{ Transfer to newly retired (million $\mathrm{CHF}$ ) } \\
\hline & Men & Women & Men & Women & Men $(\%)$ & Women (\%) & $\operatorname{Men}(\%)$ & Women (\%) & Men & Women & Total \\
\hline 2010 & 29,325 & 11,390 & 185,398 & 185,989 & 5.776 & 5.779 & 7.00 & 6.95 & $1,152,263$ & 429,439 & $1,581,702$ \\
\hline 2011 & 30,345 & 11,786 & 192,608 & 192,875 & 5.762 & 5.766 & 6.95 & 6.90 & $1,204,583$ & 447,014 & $1,651,597$ \\
\hline 2012 & 30,776 & 11,954 & 200,000 & 200,000 & 5.749 & 5.754 & 6.90 & 6.85 & $1,232,442$ & 455,582 & $1,688,024$ \\
\hline 2013 & 31,112 & 12,084 & 206,606 & 206,353 & 5.735 & 5.741 & 6.85 & 6.80 & $1,249,497$ & 460,032 & $1,709,529$ \\
\hline 2014 & 30,960 & 12,025 & 215,004 & 214,648 & 5.721 & 5.728 & 6.80 & 6.80 & $1,255,125$ & 483,068 & $1,738,193$ \\
\hline 2016 & 30,676 & 11,915 & 232,245 & 230,211 & 5.694 & 5.703 & 6.80 & 6.80 & $1,384,180$ & 527,846 & $1,912,026$ \\
\hline 2017 & 30,826 & 11,973 & 239,101 & 237,310 & 5.680 & 5.690 & 6.80 & 6.80 & $1,453,020$ & 554,183 & $2,007,203$ \\
\hline 2018 & 31,229 & 12,130 & 246,116 & 244,588 & 5.667 & 5.678 & 6.80 & 6.80 & $1,536,852$ & 586,311 & $2,123,163$ \\
\hline 2019 & 31,664 & 12,298 & 253,260 & 251,462 & 5.654 & 5.666 & 6.80 & 6.80 & $1,626,062$ & 619,172 & $2,245,234$ \\
\hline 2020 & 32,388 & 12,580 & 260,578 & 265,586 & 5.641 & 5.654 & 6.80 & 6.80 & $1,734,838$ & 677,441 & $2,412,279$ \\
\hline 2021 & 33,329 & 12,945 & 268,064 & 265,586 & 5.628 & 5.642 & 6.80 & 6.80 & $1,861,414$ & 705,883 & $2,567,297$ \\
\hline 2022 & 34,585 & 13,433 & 275,670 & 272,865 & 5.615 & 5.630 & 6.80 & 6.80 & $2,012,636$ & 761,885 & $2,774,520$ \\
\hline 2023 & 35,111 & 13,637 & 283,429 & 280,352 & 5.602 & 5.618 & 6.80 & 6.80 & $2,128,043$ & 804,301 & $2,932,345$ \\
\hline 2025 & 36,942 & 14,349 & 299,017 & 295,772 & 5.577 & 5.595 & 6.80 & 6.80 & $2,422,278$ & 914,009 & $3,336,288$ \\
\hline 2026 & 37,796 & 14,680 & 307,070 & 295,156 & 5.565 & 5.584 & 6.80 & 6.80 & $2,576,228$ & 943,876 & $3,520,104$ \\
\hline 2027 & 38,637 & 15,007 & 309,273 & 294,260 & 5.553 & 5.572 & 6.80 & 6.80 & $2,684,607$ & 972,831 & $3,657,437$ \\
\hline 2028 & 39,939 & 15,512 & 311,405 & 293,371 & 5.541 & 5.561 & 6.80 & 6.80 & $2,827,255$ & $1,013,608$ & $3,840,862$ \\
\hline 2029 & 40,915 & 15,892 & 313,565 & 295,301 & 5.529 & 5.550 & 6.80 & 6.80 & $2,950,550$ & $1,056,689$ & $4,007,240$ \\
\hline 2030 & 41,089 & 15,959 & 315,670 & 297,283 & 5.517 & 5.539 & 6.80 & 6.80 & $3,017,159$ & $1,079,813$ & $4,096,972$ \\
\hline
\end{tabular}




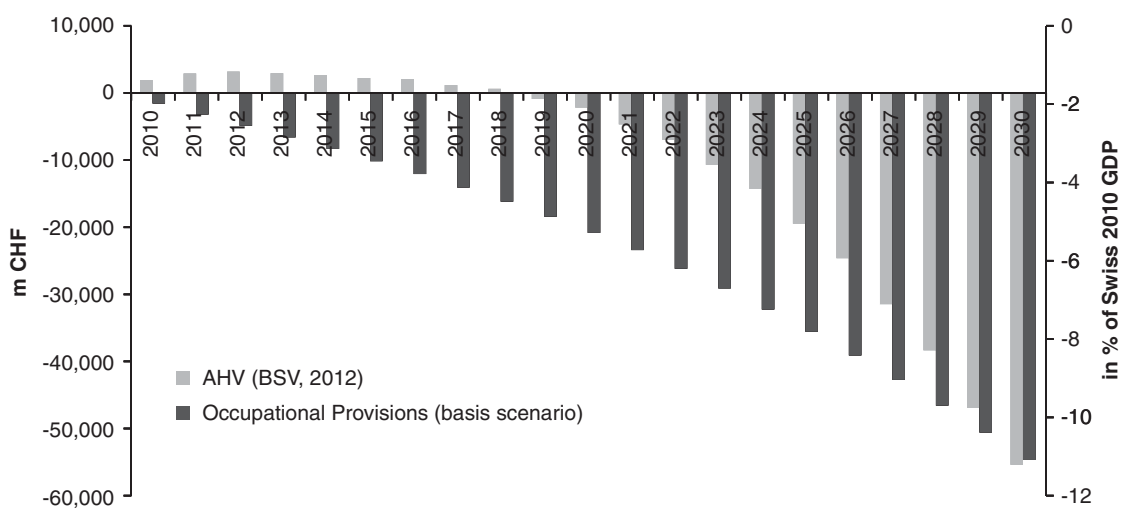

Figure 2. Financial perspective of AHV and occupational pensions (million CHF).

paid by future generations. ${ }^{30}$ Interestingly, the Swiss Confederation's current public debt is CHF 110 billion, that is, nearly exactly the same amount as the projected pension deficit, highlighting that this is a matter of serious concern.

\section{Sensitivity tests}

In Table 4, we consider alternative interest rates (1.5-4.5 per cent), demographic assumptions (deep, middle, high) and projection horizons (2010-2060) to test the robustness of the main results from the section "Main results". These tests are also important for discovering what is driving the results. As shown in Table 4, there are double-digit billion CHF transfers in all scenarios and, in many cases, the transfer volumes are much larger compared with those found for the base scenario in the section "Main results". Thus, even under very optimistic assumptions, substantial transfers occur at the expense of future generations.

We first analyse different interest rate scenarios, that is, we vary the interest rate between 1.5 and 4.5 per cent (Panel A). An interest rate of 1.5 per cent is realistic in the long run if Switzerland (similar to Japan) has a sustained low interest rate scenario and thus a continuation of the current low rates. The value of 3.5 per cent is the current reference rate according to FRP 4 and is used in the baseline scenario. ${ }^{31}$ A simulation of the expected reference rate according to FRP 4 over the next 10 years (see www.technischer-zinssatz.ch/ de/simulation/) shows, however, that between 2012 and 2021 the reference rate will decrease from 3.5 to 1.9 per cent. The interest rate of 4.5 per cent assumes a very positive development of capital markets, which seems unlikely at the present time. Thus, the baseline scenario interest rate of 3.5 per cent is a relatively positive estimate of the future interest rate.

${ }^{30}$ These billions are newly created and added to the existing funding gaps discussed in the section "The Swiss retirement system", which, in the occupational pensions, are already estimated to be CHF 41.8 billion. See BSV (2012b).

31 As an alternative to assuming a constant interest rate over time, we could use an annual adjustment according to the simulation of the reference rate for FRP4. Other industry representatives recommend significantly lower interest rates. For example, Swisscanto (2012) currently recommends 2.75 per cent, which is based on a formula that weights the investment return of the last 20 years to two-thirds and the yield on 10-year government bonds to one-third. 
Table 4 Results of sensitivity tests (in million CHF)

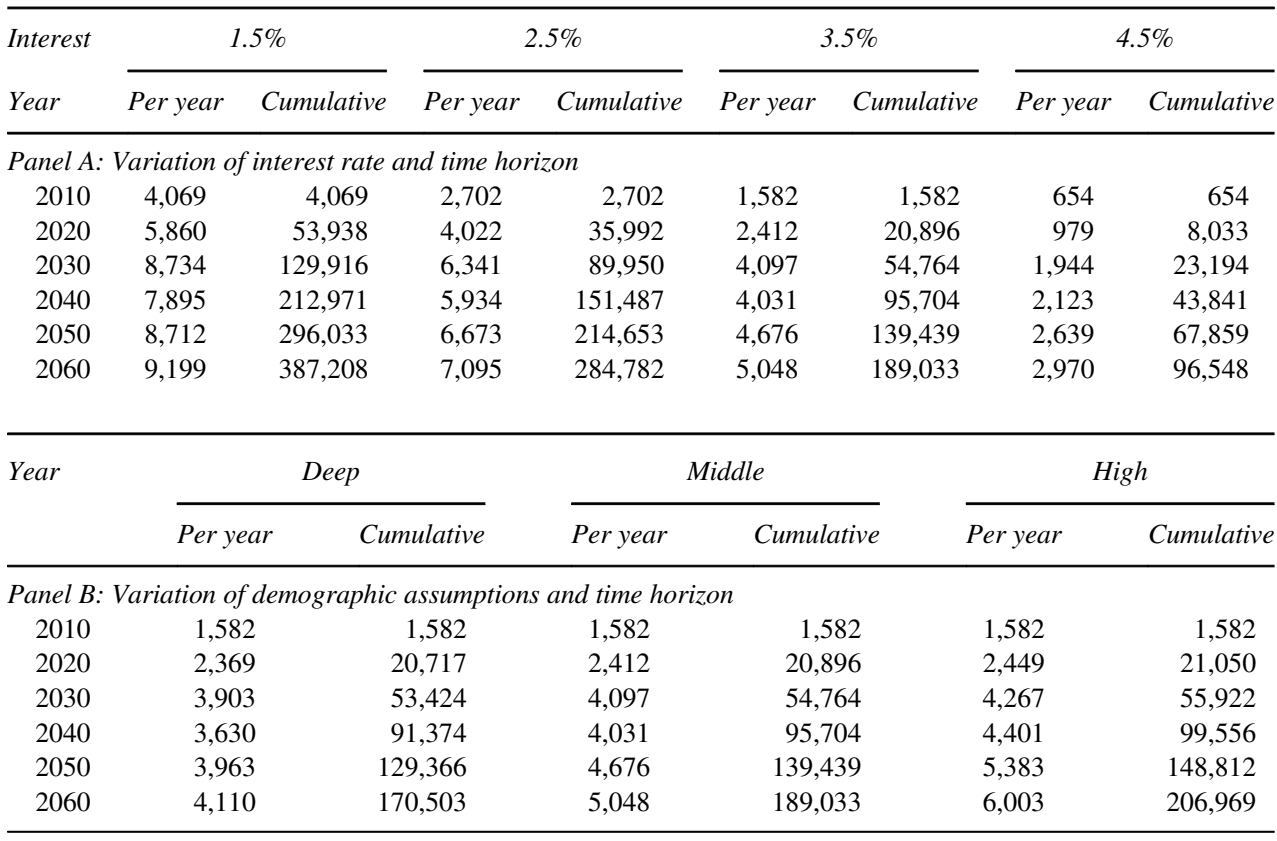

The interest rate has a significant impact on the sensitivity test results. For example, an interest rate of only 1.5 per cent significantly reduces the fair conversion rate and thus significantly increases the intergenerational transfer. Especially noteworthy are the results when an optimistic 4.5 per cent interest rate is assumed. Even in this scenario, there will be a cumulative transfer of CHF 23.2 billion by the year 2030. This finding particularly emphasises the need for reform, in that it implies a transfer from active workers to new retirees in the double-digit billions of $\mathrm{CHF}$ even if the capital markets develop in an extremely positive manner.

Panel B of Table 4 shows the results of the redistribution analysis for the Federal Office of Statistics, 32 alternative population scenarios. The "deep" scenario assumes a declining birth rate, a constant life expectancy and a stagnant population. The "high" scenario uses a higher birth rate, longer life expectancy and a growing population. The basic scenario ("middle" scenario) is shown in the middle of the table. In all three scenarios, we choose an interest rate of 3.5 per cent. Altering the demographic scenarios changes the results very little. The cumulative redistribution by 2030 varies between CHF 53.4 billion and CHF 55.9 billion. Compared with what happens when the interest rate is varied, the changes are negligible. This is a remarkable result, since it shows that regardless of demographic development, there is a need for action. The results are less sensitive than corresponding demographic

\footnotetext{
${ }^{32}$ Federal Office of Statistics (2010).
} 
projections for the AHV shown in Figure 1, which is a meaningful finding in light of the system differences set out in Table $2 .^{33}$

Another input parameter is the time horizon, which was set to 2030 in the baseline scenario. In Table 4, we extend the observation period to 2060, for different interest rates (Panel A) and different demographic assumptions (Panel B). Both panels reveal massive time effects, again emphasising the need for reform today.

In addition to the results shown here, we conducted various other sensitivity tests. ${ }^{34}$ None of the tested variations changed the main result of the analysis, that is, there will be massive funding gaps - to the tune of double-digit billion $\mathrm{CHF}$ - in the occupational pension system in the next years. Consequently, it is necessary to take action now to ensure the sustainability of the retirement system.

\section{Implications for policymakers}

The main result from the previous section is that there are financial imbalances in both the pay-as-you-go first pillar and in the occupational pension system, the second pillar. In the first pillar, financial transfers from the young to the old are part of the system; however, this is not the case in the occupational pension system, where, in principle, every employee accumulates his or her own pension. In this section we argue that intended solidarity transfers need to be transparent and fair and that unintended solidarity transfers need to be, at the very least, reduced and, preferably, eliminated.

When redistribution is not part of the system, it seems obvious to reduce and eliminate the redistribution so as to preserve the conceptual integrity of the system. When redistribution from the young to the old is part of the system, it should be designed to be sustainable and fair. By "sustainable and fair" we mean that one generation is not systematically disadvantaged relative to another. Owing to the massive financial imbalances shown in Figure 1, it seems that the current situation falls far short of intergenerational fairness. Accordingly, for the AHV, the main goal should be that contributions and expenditures

${ }^{33}$ The only demographic aspect in the second pillar is the number of new retirees, while in the first pillar, both income and expenditures (i.e. number of active people paying contributions and the number of retirees) depend on demographic assumptions. Table A3 in the Appendix shows the number of new retirees for the three demographic scenarios based on projections by the Federal Office of Statistics (2010). It can be seen that until 2020, differences between the three scenarios are not very pronounced. From 2020 onwards, the majority of the baby boomer generation will retire, which is why the AHV deficits increase. As shown in Figure 2, for the second pillar, the deficit development over time is more linear and not extremely affected by demographic assumptions. The impact of demographic assumptions thus reflects the differences between a pay-as-you-go (first pillar) and a capital-funded (second pillar) system.

${ }^{34}$ These include varying the assumptions about the coordinated wage, which we assume to be constant in the baseline scenario. An even more realistic extrapolation would involve an increase of the coordinated wage over time and thus higher transfer volumes, and we made this extrapolation in another sensitivity analysis. In addition, we consider annual payment of pensions. An alternative calculation using monthly pension payments would lead to slightly higher conversion rates. Owing to the degrees of freedom, the numbers presented here should not be taken as point estimates under certainty. Nevertheless, the numbers show that a significant transfer takes place to the detriment of the young generation, thus threatening the stability of the intergenerational contract. 
Table 5 Potential reform measures

A. Reform measures that affect both AHV and occupational provisions $\rightarrow$ The retirement age

(1) Increase statutory retirement age

- Direct and immediate increase (e.g. 65 for women)

(2) Increase actual retirement age

- Stepwise increase (e.g. to 67 years in 2027)

- Create incentives for later retirement

- Coupling retirement age to life expectancy

- Reduce incentives for early retirement

- Coupling retirement age to work history

B. Measures that affect only $A H V \rightarrow$ Strengthen solidarity, ensure sustainability and fairness

(1) Contributions

- Increase the contribution rate

(2) Benefits

- Sustainability factor in the pension calculation

- AHV+ (increase AHV minimum)

(3) Other sources of finance

- Value-added taxes

- Inheritance tax

(4) Introduction of a debt brake for the AHV that affects contributions and benefits

C. Measures that affect only occupational provisions $\rightarrow$ Strengthen idea of insurance, eliminate transfers

(1) Contributions

- Increase the contribution rate

- Start earlier (before age of 25)

(2) Benefits

- Reduce conversion rate

- Split pension into fixed and variable elements (depending on capital markets)

- Separate fund for pensions from age 85 onwards

balance. For occupational pensions, however, the legally fixed conversion rate should not systematically lead to the transfer of assets from the active population to new retirees.

Table 5 sets out possible reforms to the Swiss retirement system. In principle, there are four ways of improving the sustainability of the pension system: higher contributions, lower pensions, working longer (start earlier, retire later) and/or funding from external sources (e.g. value-added tax, inheritance tax). All these measures are politically problematic. Higher contributions burden the younger generation, increase labour costs and reduce the country's competitiveness. An ageing population makes the suggestion of reduced pensions unfeasible politically. Financing from external sources increases cross-subsidisation and further reduces transparency of the system. ${ }^{35}$ Raising the retirement age is another politically controversial issue; some people would be willing to work longer, but for others, for example, those employed in physically demanding jobs, this might not even be possible. In short, there is no silver bullet. However, neither is it an option to do nothing: the system is in imbalance and getting worse all the time. Perhaps a combination of reforms is the solution.

In discussing possible reforms, it is important to distinguish between the first and second pillars of the Swiss retirement system. In principle, it would be useful to reform the pension system as a whole, since there are areas of reform that affect both pillars, especially the retirement age. But there are also many areas of reform specific to the AHV or applicable to only the occupational pension system. For example, a tax subsidy is discussed only in

${ }^{35}$ For example, a VAT increase of 1 per cent could make a significant contribution to financing the AHV, but it also raises the question of social justice if poor people are more heavily affected by the increase. Even if an inheritance tax (which does not exist in Switzerland at the moment) were introduced, the "take" from it is unknown. 


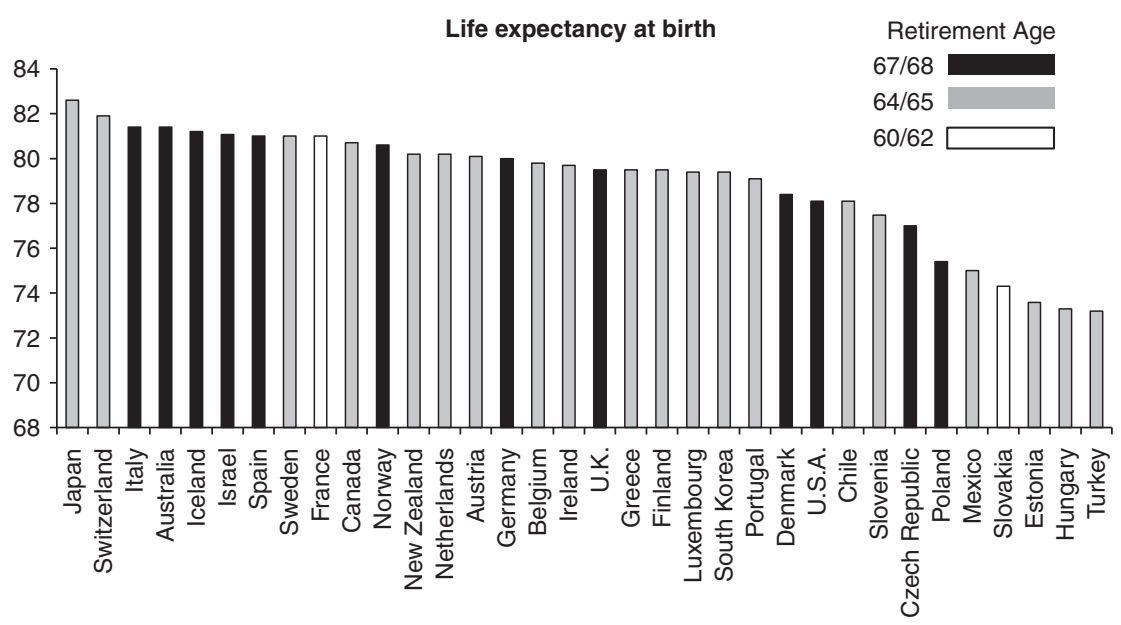

Figure 3. Life expectancy at birth and retirement age (Data: OECD and CIA World Factbook).

reference to stabilising the AHV, while the conversion rate is applicable only to occupational pensions. $^{36}$

In the following, we discuss reforms of the Swiss pension system that affect redistribution from active workers to new retirees. We focus on retirement age and the conversion rate and outline reform alternatives and their interaction. ${ }^{37}$ As the discussion will reveal, there are many alternatives for reforming the pension system. The question of which measure or package of measures should be adopted must be answered via a political process. In light of the results presented in the previous section, however, it appears important that whatever is to be done, must be done quickly.

\section{Retirement age}

Demographic change poses major challenges not only for Switzerland, but for many industrialised countries. According to the OECD ${ }^{2}$ Switzerland has the second highest life expectancy in the world. However, its retirement age is lower than other OECD countries, many of which have already implemented a pension-eligible age of 67 or older (see Figure 3). In Switzerland, the retirement age for women is 64 and for men 65.

A natural solution, then, would be to increase the retirement age. This could be done gradually, which is politically feasible as people often do not object as strongly to something that is going to take place over a long period of time. Indeed, there is usually a long transition

${ }^{36}$ Another measure specific to the AHV is an increase of the AHV minimum, called AHV+, a reform initiative by the Swiss Federation of Trade Unions SGB. The financing is proposed to be done via the introduction of new taxes and a new allocation of existing taxes.

${ }^{37}$ It is beyond the scope of this paper to discuss all the reform measures listed in Table 5. We thus focus on retirement age and the conversion rate since-next to the increase in contributions-these are the two principal measures available and widely discussed, for example, in the current reform agenda of the Swiss Federal Council. Moreover, these two measures can be easily embedded in our model framework without further assumptions. 
period for increases in the retirement age. For example, Germany is raising the retirement age from 65 to 67 years over the span from 2012 to 2027 and in the United Kingdom, the retirement age will gradually increase to 68 by the year $2046 .^{38}$

Another option is the indexing of retirement age to life expectancy, as done, for example, in Denmark. Under this system, retirement age is adjusted based on the difference between the then current life expectancy of 60-year-old persons and the life expectancy of a 60-yearold in the year 2004/2005 (81.4 years) (p. 195). ${ }^{39}$ Adjustment of the retirement age to the value will first be done in 2015 for the retirement year 2030, so that the persons concerned have 15 years to adjust to their personal retirement age. Based on this mechanism, it is expected that the statutory retirement age in Denmark in 2045 will be 71 years, and 72.5 years by 2060 . The German Council of Economic Experts ${ }^{39}$ recommends introduction of a rules-based adjustment of the retirement age to life expectancy. ${ }^{40}$

Another important consideration is how statutory retirement age compares with actual retirement age. Likely due to its good economic situation and low unemployment, Switzerland is in an advantageous situation compared with neighbouring countries in that actual retirement age is relatively high. For example, according to the OECD, ${ }^{41}$ Swiss men, on average, are 65.5 years old when they retire; in Germany, the average age of retirement for men is 61.9 years and in Austria it is 60.4 years. This further supports the idea that an increase in retirement age is a promising approach to increasing the sustainability of the retirement system.

To analyse how an increase in retirement age affects the results presented in the previous section, we redid the analysis making the assumption that from 2013 (Panel A) or 2020 (Panel B) onwards, the retirement age is increased to 65, 66 or 67 years (currently the retirement age is 64 for women and 65 for men). The situation " $65 / 65$ " in Panel B, that is, an increase of retirement age to 65 for women from 2020 onwards, is currently proposed by the Swiss Federal Council. The results of these tests are presented in Table 6.

Table 6 shows that an increase of retirement age to 65 for women in 2020 (the current reform proposal by the Swiss Federal Council) hardly affects the deficits presented in Table 4. For example, in 2030, we observe a reduction of the transfer from CHF 54,764 million to CHF 52,748 million, that is, by 3.7 per cent. There are two reasons for the relatively small reduction. First, the increase affects only the population of working women, which is smaller than the population of working men. Second, the increase comes relatively late. For example, if the reform could be implemented as soon as 2013, the reduction would already be 4.3 per cent (to CHF 52,417 million).

Then, an increase in retirement age by one year for men and women reduces the deficits by approximately CHF 7,500 million if implemented in 2013 and by CHF 6,500 million if implemented in 2020 (again looking at the deficit in 2030). This shows that an increase in retirement age significantly reduces the financial transfers. However, increasing the

\footnotetext{
38 See Bonoli (2011).

39 See Sachverständigenrat (2011).

${ }^{40}$ Another measure Germany has taken and one that could be interpreted as a possible debt brake for the AHV is the sustainability factor. According to this regulation, the actual pension depends on the ratio of the number of contributors to the number of beneficiaries. Such self-regulating mechanisms have the advantage of securing the financial stability of the pension system in the long term by automatically coupling pensions and contributions to economic and demographic changes.

41 OECD (2011)
} 
The Geneva Papers on Risk and Insurance-Issues and Practice

716

Table 6 Results of sensitivity tests for increased retirement age (in million CHF)

\begin{tabular}{|c|c|c|c|c|c|c|c|c|}
\hline \multirow{2}{*}{$\begin{array}{l}\text { Model } \\
\text { Year }\end{array}$} & \multicolumn{2}{|c|}{$64 / 65$} & \multicolumn{2}{|c|}{$65 / 65$} & \multicolumn{2}{|c|}{$66 / 66$} & \multicolumn{2}{|c|}{$67 / 67$} \\
\hline & Per year & Cumulative & Per year & Cumulative & Per year & Cumulative & Per year & Cumulative \\
\hline \multicolumn{9}{|c|}{ Panel A: Increase of retirement age from 2013 onwards } \\
\hline 2020 & 2,412 & 20,896 & 2,305 & 19,894 & 1,948 & 16,547 & 1,639 & 13,625 \\
\hline 2030 & 4,097 & 54,764 & 4,020 & 52,417 & 3,557 & 44,697 & 3,042 & 37,281 \\
\hline 2040 & 4,052 & 99,756 & 3,957 & 96,667 & 3,705 & 85,819 & 3,371 & 74,588 \\
\hline 2050 & 4,676 & 139,439 & 4,581 & 135,486 & 4,230 & 121,705 & 3,930 & 107,316 \\
\hline 2060 & 5,048 & 189,033 & 4,992 & 184,293 & 4,745 & 167,623 & 4,523 & 149,858 \\
\hline \multicolumn{9}{|c|}{ Panel B: Increase of retirement age from 2020 onwards } \\
\hline 2020 & 2,412 & 20,896 & 2,400 & 20,799 & 2,400 & 20,799 & 2,400 & 20,799 \\
\hline 2030 & 4,097 & 54,764 & 4,016 & 52,748 & 3,553 & 46,298 & 3,038 & 40,425 \\
\hline 2040 & 4,031 & 95,704 & 3,972 & 97,080 & 3,719 & 87,485 & 3,383 & 77,782 \\
\hline 2050 & 4,676 & 139,439 & 4,613 & 136,121 & 4,259 & 123,566 & 3,956 & 110,679 \\
\hline 2060 & 5,048 & 189,033 & 5,035 & 185,337 & 4,786 & 169,863 & 4,562 & 153,564 \\
\hline
\end{tabular}

Table 7 Interaction between life expectancy at retirement, interest rate and conversion rate

\begin{tabular}{|c|c|c|c|c|}
\hline Year & & $\begin{array}{l}\text { Life expectancy at } \\
\text { retirement age }\end{array}$ & $\begin{array}{l}\text { Interest } \\
\text { rate }(\%)\end{array}$ & $\begin{array}{c}\text { Fair conversion } \\
\text { rate }(\%)\end{array}$ \\
\hline 1985 & Mandatory introduction of occupational provisions & $\begin{array}{l}\text { men: } 15 \text { years } \\
\text { women: } 19 \text { years }\end{array}$ & 4.0 & 7.2 \\
\hline 2003 & First BVG revision & $\begin{array}{l}\text { men: } 18 \text { years } \\
\text { women: } 21 \text { years }\end{array}$ & 4.0 & 6.8 \\
\hline 2012 & Fair conversion rate today & $\begin{array}{l}\text { men: } 20 \text { years } \\
\text { women: } 23 \text { years }\end{array}$ & 3.5 & 5.8 \\
\hline 2030 & Fair conversion rate in 2030 & $\begin{array}{l}\text { men: } 22 \text { years } \\
\text { women: } 25 \text { years }\end{array}$ & 3.5 & 5.5 \\
\hline
\end{tabular}

retirement age alone might not be sufficient to completely eliminate the intergenerational transfer, since the increase in retirement age has to be very extreme to avoid the adverse scenarios. We thus conclude that increasing the retirement age is not sufficient in itself but needs to be combined with other elements if the reform is going to have any substantial effect.

\section{Conversion rate}

Table 7 shows the interaction between contingent life expectancy at retirement, interest rate and the fair conversion rate for different reference dates. When the Swiss occupational pension system became mandatory in 1985 , the fair conversion rate was 7.2 per cent. This was fixed by the legislature based on the then applicable life expectancy and the then prevailing interest rate. Since then, however, life expectancy has increased significantly and the interest rate has decreased significantly. In political debate in Switzerland today, the values 6.4 and 5.8 per cent are often mentioned: 6.4 per cent is the conversion rate that was rejected in a vote on the second revision of the occupational pension system in 2010 . Currently, this value seems much too high. The other figure, 5.8 per cent, apart from being 
the fair conversion rate used in this paper, is the value that some well-known pension funds grant their retirees in the non-mandatory part of the system, such as, for example, the pension fund of the Swiss national railway SBB. Looking to the future, the fair conversion rate will be 5.5 per cent in the year 2030 if the interest rate remains at 3.5 per cent. This result emphasises the need to reduce the conversion rate in the future, given the current retirement age, as life expectancy continues to increase.

It is important to mention the interaction between retirement age and conversion rate. An increase in the retirement age and a reduction in the conversion rate go hand in hand because the conversion rate is a function of the retirement age. Thus, reducing the conversion rate can be avoided by increasing the retirement age. To what extent the retirement age will need to be increased can be discovered from the model presented in the previous section.

This connection is illustrated in Table 8. For example, if a fair conversion rate of 5.75 per cent is maintained over the years (despite the increase in life expectancy), men need to work until age 66 in 2022, until age 67 in 2032, until age 68 in 2043 and until age 69 in 2054. Based on their current retirement age of 64 , the retirement age for women would have to be 65 in 2023, 66 in 2034, 67 in 2046 and 68 in 2058 to keep the situation fair. ${ }^{42}$ Note that in Table 8, for the year 2012, the current statutory conversion rate of 6.9 per cent for men and 6.85 per cent for women is not shown, indicating that the necessary retirement age for granting this pension rate is higher than 70 years. This again illustrates that the current conversion rates in the mandatory part of the occupational pension system are much too high.

To analyse how a decrease in the conversion rate affects the results presented in the previous section, we redid the analysis making the assumption that from 2013 (Panel A) or 2020 (Panel B) onwards the conversion rate will be decreased to 6.4, 6.0, or 5.8 per cent. The situation of 6.0 per cent from 2020 onwards represents what is currently proposed by the Swiss Federal Council. The results of these tests are presented in Table 9.

Decreasing the conversion rate reduces the financial deficits more substantially than does increasing the retirement age (see Table 6). For example, for the year 2030, reducing the conversion rate to 6.4 per cent reduces the financial transfers in an amount comparable with that achieved by increasing the retirement age to 67 years (to approximately CHF 37,000 million). A conversion rate of 5.8 per cent reduces the transfer amount to $\mathrm{CHF}$ 12,819 million. However, the transfer can never be completely eliminated with this type of reform.

\section{Combination of increased retirement age and reduced conversion rate}

To develop a set of reform measures that completely eliminates the transfer, we now analyse combinations of an increased retirement age and a reduced conversion rate. In Table 10,

${ }^{42}$ We thus need to increase the retirement age by one year every 11 to 12 years if the system is to continue without other changes. This is because the average life expectancy in Switzerland increases every year by one month. The fact that men have a more rapid adjustment reflects that the life expectancy for men is rising slightly faster than that for women. Based on today's remaining life expectancy at age 65 of 18 and 23 years (i.e. a life expectancy of 83 or 88 years if the age of 65 is achieved), the Federal Office of Statistics projects a remaining life expectancy of 23 years for men in 2050 and a life expectancy for women of 26 years if age 65 is achieved. Accordingly, the life expectancy for men is growing a bit faster in these projections. 
Table 8 Fair conversion rates in \% for the years 2010-2060 depending on retirement age

\begin{tabular}{|c|c|c|c|c|c|c|c|c|c|c|c|c|c|}
\hline \multirow[t]{2}{*}{ Year } & \multicolumn{6}{|c|}{$\begin{array}{l}\text { Fair conversion rates for men } \\
\text { depending on retirement age }\end{array}$} & \multicolumn{7}{|c|}{$\begin{array}{c}\text { Fair conversion rates for women } \\
\text { depending on retirement age }\end{array}$} \\
\hline & 65 & 66 & 67 & 68 & 69 & 70 & 64 & 65 & 66 & 67 & 68 & 69 & 70 \\
\hline 2010 & 5.78 & & & & & & 5.78 & 5.92 & & & & & \\
\hline 2011 & 5.76 & 5.91 & & & & & 5.77 & 5.91 & 6.06 & & & & \\
\hline 2012 & 5.75 & 5.89 & 6.04 & & & & 5.75 & 5.90 & 6.05 & 6.21 & & & \\
\hline 2013 & 5.74 & 5.88 & 6.03 & 6.19 & & & 5.74 & 5.88 & 6.03 & 6.20 & 6.37 & & \\
\hline 2014 & 5.72 & 5.86 & 6.01 & 6.17 & 6.34 & & 5.73 & 5.87 & 6.02 & 6.18 & 6.36 & 6.55 & \\
\hline 2015 & 5.71 & 5.85 & 5.99 & 6.15 & 6.32 & 6.51 & 5.72 & 5.86 & 6.01 & 6.17 & 6.34 & 6.53 & 6.74 \\
\hline 2016 & 5.69 & 5.83 & 5.98 & 6.14 & 6.30 & 6.49 & 5.70 & 5.84 & 5.99 & 6.15 & 6.32 & 6.51 & 6.72 \\
\hline 2017 & 5.68 & 5.82 & 5.96 & 6.12 & 6.29 & 6.47 & 5.69 & 5.83 & 5.98 & 6.13 & 6.31 & 6.49 & 6.70 \\
\hline 2018 & 5.67 & 5.80 & 5.95 & 6.10 & 6.27 & 6.45 & 5.68 & 5.82 & 5.96 & 6.12 & 6.29 & 6.48 & 6.68 \\
\hline 2019 & 5.65 & 5.79 & 5.93 & 6.09 & 6.25 & 6.43 & 5.67 & 5.80 & 5.95 & 6.10 & 6.27 & 6.46 & 6.66 \\
\hline 2020 & 5.64 & 5.77 & 5.92 & 6.07 & 6.24 & 6.41 & 5.65 & 5.79 & 5.93 & 6.09 & 6.26 & 6.44 & 6.64 \\
\hline 2021 & 5.63 & 5.76 & 5.90 & 6.06 & 6.22 & 6.39 & 5.64 & 5.78 & 5.92 & 6.07 & 6.24 & 6.42 & 6.62 \\
\hline 2022 & 5.61 & 5.75 & 5.89 & 6.04 & 6.20 & 6.38 & 5.63 & 5.76 & 5.91 & 6.06 & 6.23 & 6.41 & 6.60 \\
\hline 2023 & 5.60 & 5.73 & 5.87 & 6.02 & 6.19 & 6.36 & 5.62 & 5.75 & 5.89 & 6.05 & 6.21 & 6.39 & 6.58 \\
\hline 2024 & 5.59 & 5.72 & 5.86 & 6.01 & 6.17 & 6.34 & 5.61 & 5.74 & 5.88 & 6.03 & 6.20 & 6.37 & 6.57 \\
\hline 2025 & 5.58 & 5.71 & 5.85 & 5.99 & 6.15 & 6.32 & 5.60 & 5.73 & 5.87 & 6.02 & 6.18 & 6.36 & 6.55 \\
\hline 2026 & 5.56 & 5.69 & 5.83 & 5.98 & 6.14 & 6.31 & 5.58 & 5.71 & 5.85 & 6.00 & 6.16 & 6.34 & 6.53 \\
\hline 2027 & 5.55 & 5.68 & 5.82 & 5.96 & 6.12 & 6.29 & 5.57 & 5.70 & 5.84 & 5.99 & 6.15 & 6.32 & 6.51 \\
\hline 2028 & 5.54 & 5.67 & 5.80 & 5.95 & 6.11 & 6.27 & 5.56 & 5.69 & 5.83 & 5.98 & 6.13 & 6.31 & 6.50 \\
\hline 2029 & 5.53 & 5.66 & 5.79 & 5.93 & 6.09 & 6.26 & 5.55 & 5.68 & 5.81 & 5.96 & 6.12 & 6.29 & 6.48 \\
\hline 2030 & 5.52 & 5.64 & 5.78 & 5.92 & 6.07 & 6.24 & 5.54 & 5.67 & 5.80 & 5.95 & 6.11 & 6.28 & 6.46 \\
\hline 2031 & 5.51 & 5.63 & 5.76 & 5.91 & 6.06 & 6.22 & 5.53 & 5.66 & 5.79 & 5.93 & 6.09 & 6.26 & 6.45 \\
\hline 2032 & 5.49 & 5.62 & 5.75 & 5.89 & 6.04 & 6.21 & 5.52 & 5.64 & 5.78 & 5.92 & 6.08 & 6.25 & 6.43 \\
\hline 2033 & 5.48 & 5.61 & 5.74 & 5.88 & 6.03 & 6.19 & 5.51 & 5.63 & 5.77 & 5.91 & 6.06 & 6.23 & 6.41 \\
\hline 2034 & 5.47 & 5.59 & 5.72 & 5.86 & 6.01 & 6.18 & 5.50 & 5.62 & 5.75 & 5.90 & 6.05 & 6.22 & 6.40 \\
\hline 2035 & 5.46 & 5.58 & 5.71 & 5.85 & 6.00 & 6.16 & 5.49 & 5.61 & 5.74 & 5.88 & 6.03 & 6.20 & 6.38 \\
\hline 2036 & 5.45 & 5.57 & 5.70 & 5.84 & 5.99 & 6.14 & 5.48 & 5.60 & 5.73 & 5.87 & 6.02 & 6.19 & 6.36 \\
\hline 2037 & 5.44 & 5.56 & 5.69 & 5.82 & 5.97 & 6.13 & 5.47 & 5.59 & 5.72 & 5.86 & 6.01 & 6.17 & 6.35 \\
\hline
\end{tabular}




\begin{tabular}{|c|c|c|c|c|c|c|c|c|c|c|c|c|c|}
\hline 2038 & 5.43 & 5.55 & 5.67 & 5.81 & 5.96 & 6.11 & 5.46 & 5.58 & 5.71 & 5.84 & 5.99 & 6.16 & 6.33 \\
\hline 2039 & 5.42 & 5.53 & 5.66 & 5.80 & 5.94 & 6.10 & 5.45 & 5.57 & 5.69 & 5.83 & 5.98 & 6.14 & 6.32 \\
\hline 2040 & 5.40 & 5.52 & 5.65 & 5.78 & 5.93 & 6.08 & 5.44 & 5.56 & 5.68 & 5.82 & 5.97 & 6.13 & 6.30 \\
\hline 2041 & 5.39 & 5.51 & 5.64 & 5.77 & 5.91 & 6.07 & 5.43 & 5.55 & 5.67 & 5.81 & 5.95 & 6.11 & 6.29 \\
\hline 2042 & 5.38 & 5.50 & 5.63 & 5.76 & 5.90 & 6.05 & 5.42 & 5.53 & 5.66 & 5.80 & 5.94 & 6.10 & 6.27 \\
\hline 2043 & 5.37 & 5.49 & 5.61 & 5.75 & 5.89 & 6.04 & 5.41 & 5.52 & 5.65 & 5.78 & 5.93 & 6.09 & 6.26 \\
\hline 2044 & 5.36 & 5.48 & 5.60 & 5.73 & 5.87 & 6.03 & 5.40 & 5.51 & 5.64 & 5.77 & 5.92 & 6.07 & 6.24 \\
\hline 2045 & 5.35 & 5.47 & 5.59 & 5.72 & 5.86 & 6.01 & 5.39 & 5.50 & 5.63 & 5.76 & 5.90 & 6.06 & 6.23 \\
\hline 2046 & 5.34 & 5.46 & 5.58 & 5.71 & 5.85 & 6.00 & 5.38 & 5.49 & 5.62 & 5.75 & 5.89 & 6.05 & 6.21 \\
\hline 2048 & 5.32 & 5.44 & 5.56 & 5.68 & 5.82 & 5.97 & 5.36 & 5.47 & 5.60 & 5.73 & 5.87 & 6.02 & 6.19 \\
\hline 2049 & 5.31 & 5.43 & 5.55 & 5.67 & 5.81 & 5.96 & 5.35 & 5.46 & 5.59 & 5.72 & 5.86 & 6.01 & 6.17 \\
\hline 2050 & 5.30 & 5.42 & 5.53 & 5.66 & 5.80 & 5.94 & 5.34 & 5.45 & 5.58 & 5.70 & 5.84 & 5.99 & 6.16 \\
\hline 2051 & 5.29 & 5.41 & 5.52 & 5.65 & 5.78 & 5.93 & 5.33 & 5.45 & 5.56 & 5.69 & 5.83 & 5.98 & 6.14 \\
\hline 2052 & 5.28 & 5.39 & 5.51 & 5.64 & 5.77 & 5.92 & 5.32 & 5.44 & 5.55 & 5.68 & 5.82 & 5.97 & 6.13 \\
\hline 2053 & 5.28 & 5.38 & 5.50 & 5.63 & 5.76 & 5.90 & 5.32 & 5.43 & 5.54 & 5.67 & 5.81 & 5.96 & 6.12 \\
\hline 2054 & 5.27 & 5.37 & 5.49 & 5.62 & 5.75 & 5.89 & 5.31 & 5.42 & 5.53 & 5.66 & 5.80 & 5.94 & 6.10 \\
\hline 2055 & 5.26 & 5.37 & 5.48 & 5.60 & 5.74 & 5.88 & 5.30 & 5.41 & 5.52 & 5.65 & 5.79 & 5.93 & 6.09 \\
\hline 2057 & 5.24 & 5.35 & 5.46 & 5.58 & 5.71 & 5.85 & 5.28 & 5.39 & 5.51 & 5.63 & 5.76 & 5.91 & 6.06 \\
\hline 2058 & 5.23 & 5.34 & 5.45 & 5.57 & 5.70 & 5.84 & 5.27 & 5.38 & 5.50 & 5.62 & 5.75 & 5.90 & 6.05 \\
\hline 2059 & 5.22 & 5.33 & 5.44 & 5.56 & 5.69 & 5.83 & 5.26 & 5.37 & 5.49 & 5.61 & 5.74 & 5.88 & 6.04 \\
\hline 2060 & 5.21 & 5.32 & 5.43 & 5.55 & 5.68 & 5.81 & 5.26 & 5.36 & 5.48 & 5.60 & 5.73 & 5.87 & 6.03 \\
\hline
\end{tabular}

Note: Calculations are based on VZ 2010 tables. 
The Geneva Papers on Risk and Insurance-Issues and Practice

720

Table 9 Results of sensitivity tests for reduced conversion rate (in million CHF)

\begin{tabular}{|c|c|c|c|c|c|c|c|c|}
\hline \multirow{2}{*}{$\begin{array}{l}\text { Model } \\
\text { Year }\end{array}$} & \multicolumn{2}{|c|}{ Unchanged } & \multicolumn{2}{|c|}{$6.4 \%$} & \multicolumn{2}{|c|}{$6.0 \%$} & \multicolumn{2}{|c|}{$5.8 \%$} \\
\hline & Per year & Cumulative & Per year & Cumulative & Per year & Cumulative & Per year & Cumulative \\
\hline \multicolumn{9}{|c|}{ Panel A: Decrease of conversion rate from 2013 onwards } \\
\hline 2020 & 2,400 & 20,799 & 1,577 & 15,118 & 743 & 9,396 & 325 & 6,536 \\
\hline 2030 & 4,094 & 54,577 & 2,814 & 37,952 & 1,531 & 21,197 & 889 & 12,819 \\
\hline 2040 & 4,045 & 95,586 & 2,892 & 69,539 & 1,732 & 39,378 & 1,152 & 24,298 \\
\hline 2050 & 4,710 & 139,568 & 3,418 & 98,260 & 2,159 & 57,137 & 1,530 & 36,575 \\
\hline 2060 & 5,092 & 189,580 & 3,767 & 134,946 & 2,487 & 80,915 & 1,846 & 53,899 \\
\hline \multicolumn{9}{|c|}{ Panel B: Decrease of conversion rate from 2020 onwards } \\
\hline 2020 & 2,400 & 20,799 & 1,577 & 20,061 & 743 & 19,226 & 325 & 18,808 \\
\hline 2030 & 4,094 & 54,577 & 2,814 & 42,895 & 1,531 & 31,026 & 889 & 25,091 \\
\hline 2040 & 4,045 & 95,586 & 2,892 & 74,482 & 1,732 & 49,208 & 1,152 & 36,571 \\
\hline 2050 & 4,710 & 139,568 & 3,418 & 103,203 & 2,159 & 66,966 & 1,530 & 48,848 \\
\hline 2060 & 5,092 & 189,580 & 3,767 & 139,889 & 2,487 & 90,744 & 1,846 & 66,172 \\
\hline
\end{tabular}

we analyse four scenarios, that is, an increase in retirement age together with a decrease in the conversion rate to 6.0 per cent from 2013 and 2020 onwards, as well as an increase in retirement age together with a decrease in the conversion rate to 5.8 per cent from 2013 and 2020 onwards.

Increasing women's retirement age to 65 years together with a decrease in the conversion rate to 6.0 per cent from 2020 onwards (Table 10, Panel B) is the Swiss Federal Council's current reform proposal. This proposal substantially reduces the projected financial deficits, for example, to CHF 19,997 million in 2030 (compared with CHF 54,764 million in the baseline scenario). This is a reduction of 63 per cent, but it leaves a financial deficit of $\mathrm{CHF}$ 19,997 million for the young population. Thus the current reform agenda is moving in the right direction, but does not go far enough to eliminate the financial deficits projected for the second pillar. Again looking at the year 2030, a reduction to 5.8 per cent in combination with an increase of the retirement age to 67 would almost completely eliminate the financial transfers (the cumulative transfer is CHF 1,339 million in this case). It is unlikely that such massive changes in the retirement system can be implemented in light of political considerations, but the extent of the changes needed emphasise how unfair the current situation is for the young population.

\section{A comparison with the situation in other countries}

How do other countries regulate paying out of capital-funded systems? OECD, ${ }^{41}$ Kaschützke $^{43}$ and Antolin et al. $^{44}$ provide some information on forms of benefit payment at retirement. In our international comparison, we find very few countries that regulate paying out of capital. Given this result, one policy suggestion that might be derived from the

\footnotetext{
${ }^{43}$ Kaschützke (2009).

${ }^{44}$ Antolin et al. (2008).
} 
Table 10 Fair conversion rates depending on retirement age

\begin{tabular}{|c|c|c|c|c|c|c|c|c|}
\hline \multirow{2}{*}{$\begin{array}{l}\text { Model } \\
\text { Year }\end{array}$} & \multicolumn{2}{|c|}{$64 / 65$} & \multicolumn{2}{|c|}{$65 / 65$} & \multicolumn{2}{|c|}{$66 / 66$} & \multicolumn{2}{|c|}{$67 / 67$} \\
\hline & Per year & Cumulative & Per year & Cumulative & Per year & Cumulative & Per year & Cumulative \\
\hline \multicolumn{9}{|c|}{ Panel A: Increase of retirement age and decrease of conversion rate to $6.0 \%$ from 2013 onwards } \\
\hline 2020 & 743 & 9,396 & 655 & 8,821 & 358 & 6,929 & 66 & 5,447 \\
\hline 2030 & 1,531 & 21,197 & 1,432 & 19,516 & 1,003 & 13,838 & 550 & 8,516 \\
\hline 2040 & 1,732 & 39,378 & 1,639 & 36,729 & 1,325 & 27,210 & 957 & 17,489 \\
\hline 2050 & 2,159 & 57,137 & 2,064 & 53,633 & 1,709 & 41,022 & 1,354 & 27,955 \\
\hline 2060 & 2,487 & 80,915 & 2,412 & 76,539 & 2,109 & 60,651 & 1,793 & 43,902 \\
\hline \multicolumn{9}{|c|}{ Panel B: Increase of retirement age and decrease of conversion rate to $6.0 \%$ from 2020 onwards } \\
\hline 2020 & 743 & 9,396 & 743 & 9,396 & 743 & 9,396 & 743 & 9,396 \\
\hline 2030 & 1,531 & 21,197 & 1,432 & 19,997 & 1,003 & 15,851 & 550 & 12,263 \\
\hline 2040 & 1,732 & 39,378 & 1,639 & 37,211 & 1,325 & 29,223 & 957 & 21,236 \\
\hline 2050 & 2,159 & 57,137 & 2,064 & 54,114 & 1,709 & 43,035 & 1,354 & 31,702 \\
\hline 2060 & 2,487 & 80,915 & 2,412 & 77,021 & 2,109 & 62,664 & 1,793 & 47,649 \\
\hline \multicolumn{9}{|c|}{ Panel C: Increase of retirement age and decrease of conversion rate to 5.8\% from 2013 onwards } \\
\hline 2020 & 325 & 6,536 & 242 & 6,067 & -39 & 4,538 & -328 & 3,417 \\
\hline 2030 & 889 & 12,819 & 785 & 11,305 & 365 & 6,138 & -73 & 1,339 \\
\hline 2040 & 1,152 & 24,298 & 1,059 & 21,759 & 730 & 12,572 & 353 & 3,228 \\
\hline 2050 & 1,530 & 36,575 & 1,435 & 33,184 & 1,078 & 20,866 & 710 & 8,129 \\
\hline 2060 & 1,846 & 53,899 & 1,767 & 49,615 & 1,450 & 33,923 & 1,110 & 17,427 \\
\hline \multicolumn{9}{|c|}{ Panel D: Increase of retirement age and decrease of conversion rate to $5.8 \%$ from 2020 onwards } \\
\hline 2020 & 325 & 6,536 & 325 & 6,536 & 325 & 6,536 & 325 & 6,536 \\
\hline 2030 & 889 & 12,819 & 785 & 11,778 & 365 & 8,213 & -73 & 5,200 \\
\hline 2040 & 1,152 & 24,298 & 1,059 & 22,232 & 730 & 14,647 & 353 & 7,089 \\
\hline 2050 & 1,530 & 36,575 & 1,435 & 33,657 & 1,078 & 22,941 & 710 & 11,990 \\
\hline 2060 & 1,846 & 53,899 & 1,767 & 50,088 & 1,450 & 35,997 & 1,110 & 21,288 \\
\hline
\end{tabular}

international comparison is to deregulate the conversion rate and delegate the decision for setting it, for example, to the board of the pension fund. We present the cases of Germany, Sweden, the United States and Iceland to illustrate variants in regulation.

In Germany, the legislator requires a money-back guarantee, but does not impose additional regulations on the paying out of capital. In Sweden, the beneficiary can choose to keep the capital in a preselected fund, in which case the pension is recalculated every year depending on how the value of the funds has developed. There is no other regulation. ${ }^{45}$ In the United States, retirement plans are not subject to extensive regulation. An exception is the mandatory minimum distribution for Individual Retirement Accounts starting at the age of $701 / 2$, which is a tax-motivated regulation. This calculation uses actuarial principles and is based on a joint life expectancy table published by the Internal Revenue Service. ${ }^{46}$ Iceland is

\footnotetext{
${ }^{45}$ See Kaschützke (2009, p. 269). See Lindquist and Wadensjö (2009) for more details on the Swedish system.

${ }^{46}$ For details, see Kaschützke (2009, pp. 303-314).
} 
the country most similar to Switzerland in regard to its retirement system. As in Switzerland, the government sets contribution rates, minimum rates of return and the annuity rate at which the accumulation is converted into a pension for mandatory occupational plans. Both these schemes are therefore implicitly defined benefit plans (p. 107). ${ }^{41}$

\section{Limitations of the analysis}

\section{Age-specific labour market participation}

A limitation of the analyses presented in the previous section is that we assume that individual behaviour is independent of the retirement institutions and fixed over time. Potential changes to retirement behaviour based on changes to the retirement institutions (e.g. later retirement age) are not accounted for in the projections. This assumption has serious implications, as economic literature shows that changes to retirement systems lead to earlier or later retirement, thereby changing the stream of savings before, and the stream of payments after retirement. ${ }^{47}$

To account for this aspect we might integrate assumptions on age-specific labour force participation rates and unemployment rates. However, as long as early and late retirement are accounted for using actuarially correct adjustments to the pensions, the effect on the redistribution numbers presented in this paper should be limited. Even if the conditions are not actuarially correct, the direction and magnitude of their impact remain empirically unclear and can be analysed only by making numerous other assumptions.

\section{Focus on mandatory occupational pension system}

We project financial deficits resulting from the high statutory conversion rate and interpret these as intergenerational transfers. This is, however, an isolated consideration which neglects other potential redistributions in the second pillar. Since only parts of the premium in the second pillar are used for the pension, other redistributions might arise from the benefits for surviving dependents and in case of invalidity. Moreover, profits from investing the premiums are not completely allocated to the policyholder, but are distributed among shareholders and policyholders following a predefined surplus participation mechanism. Finally, next to the mandatory occupational plans (where the government sets the conditions), there is also the non-mandatory part of the system, where other conditions are offered.

${ }^{47}$ Regarding firm pension plan provisions, Stock and Wise (1990) model the retirement decisions of older employees focusing on the "option value" of continued work. Samwick (1998) estimates the combined effect of social security and pension benefits on the probability of retirement in a cross-section of the population near retirement age. In an international comparison of 12 countries, Gruber and Wise (2004) show strong relationships across countries between social security programme incentives to retire and the proportion of older persons out of the labour force. Regarding Switzerland, Hanel and Riphahn (2012) show the responsiveness of individual retirement decisions to an increase in retirement age and the introduction of early retirement with a benefit discount. They show that a permanent reduction of retirement benefits by 3.4 per cent induces a decline in the age-specific annual retirement probability of more than 50 per cent. Other analyses of responses to changes in the Swiss retirement system are provided by Bütler (2002) and Dorn and Sousa-Poza (2003, 2005). 
All these elements might result in other redistributions between the active population and the retirees. ${ }^{48}$ In order to fully account for these effects and to completely model the profitability from the perspective of one policyholder, it would be necessary to look at the overall profitability of succeeding birth cohorts over their lifetimes, which is not provided in the paper. Nevertheless, the presented results are very substantial in terms of their volume and thus useful to show an increasingly relevant problem in the Swiss retirement system. Future research is necessary to model other potential redistributions and their interaction.

\section{Conclusion}

The high statutory conversion rate in the Swiss occupational pension system results in a redistribution from the active population to the newly retired that can be viewed as an unfair intergenerational transfer. We quantify these effects and outline policy measures that could improve this situation. The problems, as well as the reforms, discussed in this paper may be relevant to the reform of retirement systems in other countries, too.

In an international comparison, Bonoli et al. ${ }^{49}$ show three key factors for success of pension reform that can be used as guidelines in reforming the Swiss system. First, a broad consensus on the key elements of reform is necessary, that is, the goals of all stakeholders in the reform process (e.g. trade unions, employers, political parties) must be considered. The second key to success is self-regulatory mechanisms, that is, a de-politicisation of the decision parameters in an objective form. Finally, Bonoli et al. ${ }^{49}$ argue that fundamental and transparent reforms are better accepted than minor reforms, that is, bigger is better.

With these guidelines in hand, it seems possible to reform the Swiss retirement system, which is necessary to sustain the system and its benefit levels for future generations. We argue that the intended solidarity transfers in the pay-as-you-go system (pillar one) should be transparent and fair, while the unintended transfers in the occupational pension system (pillar two) should be reduced and, if possible, eliminated. To achieve these goals, both the retirement age and the conversion rate need to be considered. Which of these measures should be taken and to what degree is not answered in this study. Our numerical results, however, illustrate that only a combination of different measures will lead to a realistic reform agenda, since focusing on only one measure leads to extreme adaptations, for example, of the retirement age. Moreover, the numerical results illustrate that it is important to start the reform process now.

A limitation of the analysis that should be addressed in future research is that we assume that individual behaviour is independent of the retirement institutions and fixed over time. Potential changes in retirement behaviour due to changes to the retirement institutions

48 These three aspects (potential gains from risk premiums, surplus participation and the non-mandatory business) are also important to explain why some insurers are still willing to offer products in the second pillar. In fact, insurance companies are mandated to guarantee 100 per cent coverage of the pension fund. Despite this unfair requirement, some insurers are still willing to offer such products, since they can make profits from these other sources. However, the number of insurers offering products in the second pillar has been going down over the last years (see EDI, 2011, p. 63; today only seven insurers, 25 years ago 22 insurers). The already low and decreasing number of active insurers might indicate that there are problems leading to a decrease in attractiveness and thus to market exits.

${ }^{49}$ Bonoli et al. (2008). 
(e.g. statutory retirement age) are not accounted for in the projections. Dynamic general equilibrium models with overlapping generations might be a useful approach in order to validate and extend the results presented in the paper. ${ }^{50}$ A second limitation is that we only consider redistributions from the excessive high conversion rates in the mandatory occupational pension system and neglect other potential redistributions. A profitability analysis of succeeding birth cohorts over their lifetimes might be useful to completely model redistributions in the second pillar and their interaction.

\section{Acknowledgements}

I am grateful to Walter Ackermann, Semir Ben-Ammar, Christian Biener and Hato Schmeiser for valuable comments. Thanks to Philipp Kobler for research assistance in preparing this analysis.

\section{References}

Antolin, P., Pugh, C. and Stewart, F. (2008) Forms of benefit payment at retirement, OECD Working Papers on Insurance and Private Pensions, No. 26.

Aon Hewitt (2011) Swiss Pension Fund Survey 2011/12-Gesamtauswertung, Zürich: Aon Hewitt Switzerland AG, December.

Ausgleichsfonds (2012) 'Jahresbericht 2011,' Ausgleichsfonds der Alters- und Hinterlassenenversicherung, der Invalidenversicherung und der Erwerbsersatzordnung, from www.ahvfonds.ch/en/doc.cfm?grp_name=avsLib FileListing\&doc_name $=J B \_2011 \_d \_A u s g l e i c h s f o n d s \_A H V \_I V \_E O . p d f$.

Australian Centre for Financial Studies (2011) 'Melbourne Mercer Global Pension Index', from www.globalpension index.com/pdf/melbourne-mercer-global-pension-index-report-2011.pdf.

Baumann, O., Gross, A., Kistler, J., Schmidt, F., Schneiter, A. and Zingg, A. (2011) Überlegungen zur Weiterentwicklung der beruflichen Vorsorge-Leistungs- und Finanzierungskonzept, Luzern: VPS Verlag, Personalvorsorge und Sozialversicherung AG.

Bonoli, G. (2011) 'Zur Reform der Sozialversicherungssysteme in Europa', Die Volkswirtschaft 2011(1): 4-7.

Bonoli, G., Bertozzi, F. and Wichmann, S. (2008) Adaptation des systèmes de retraite dans l'OCDE: Quels modèles de réforme pour la Suisse?, Rapport de recherche No 5/08, Bern: Bundesamt für Sozialversicherungen [BSV].

Braun, A., Rymaszewski, P. and Schmeiser, H. (2011) 'A traffic light approach to solvency measurement of Swiss occupational pension funds', The Geneva Papers on Risk and Insurance-Issues and Practice 36(2): 254-282.

Bühlmann, F., Schmid Botkine, C., Farago, P., Höpflinger, F., Joye, D., Levy, R., Perrig-Chiello, P. and Suter, C. (eds) (2012) Sozialbericht 2012-Fokus Generationen, Zürich: Seismo-Verlag.

Bundesamt für Sozialversicherungen (BSV) (2006) Auswirkungen der neuen Bevölkerungsszenarien des BFS auf die Finanzierung der AHV, Bern: Bundesamt für Sozialversicherungen.

Bundesamt für Sozialversicherungen (BSV) (2011) 'Tabellen 2011 BVG-Altersguthaben', from www.bsv.admin.ch/ themen/vorsorge/00039/index. html ?lang $=$ de\&download $=N H z L p Z e g 7 t$, lnp6IONTU042l2Z6ln 1acy4Zn4Z2qZpn O2Yuq2Z6gpJCDfIJ5gGym162epYbg2c_JjKbNoKSn6A-.

Bundesamt für Sozialversicherungen (BSV) (2012a) 'Finanzperspektiven der AHV', from www.bsv.admin.ch/ ahv-gemeinsam/03101/03109/index.html?lang=de.

Bundesamt für Sozialversicherungen (BSV) (2012b) 'Bilanzsumme gegenüber Vorjahr unverändert', Medien mitteilung vom 5. November 2012, from www.bfs.admin.ch/bfs/portal/de/index/news/01/nip_detail.Document .165214.pdf.

Bundesamt für Sozialversicherungen (BSV) (2013) 'Die berufliche Vorsorge in der Schweiz: Pensionskassenstatistik 2011', Neuchâtel, from www.bfs.admin.ch/bfs/portal/de/index/themen/13/22/publ.html?publicationID=5180.

${ }^{50}$ See, for example, Gonand and Legros (2009) for an analysis of growth and intergenerational redistributive effects in the French system. 
Bütler, M. (2002) 'The political feasibility of increasing the retirement age: Lessons from a ballot on the female retirement age', International Tax and Public Finance 9(4): 349-365.

Bütler, M. (2009) 'Switzerland: High replacement rates and generous subsistence as a barrier to work in old age', The Geneva Papers on Risk and Insurance -Issues and Practice 34(4): 561-577.

Bütler, M. and Jäger, F. (2007) Die 2. Säule der schweizerischen Altersvorsorge im Wandel, St. Gallen: Forschungsinstitut für empirische Ökonomie und Wirtschaftspolitik.

Credit Suisse (2012) Herausforderungen Pensionskassen 2012: Aktuelles Stimmungsbild und Hintergründe, Zürich: Credit Suisse Economic Research.

Dorn, D. and Sousa-Poza, A. (2003) 'Why is the employment rate of older Swiss so high? An analysis of the social security system', The Geneva Papers on Risk and Insurance-Issues and Practice 28(4): 652-672.

Dorn, D. and Sousa-Poza, A. (2005) 'The determinants of early retirement in Switzerland', Swiss Journal of Economics and Statistics 141(2): 247-283.

Eidgenössisches Departement des Innern (EDI) (2011) 'Bericht des Bundesrates zuhanden der Bundesversammlung über die Zukunft der 2. Säule', from www.bsv.admin.ch/themen/vorsorge/aktuell/03157/index.html?lang=de.

Eling, M. (2012) Der Generationenvertrag in Gefahr: Eine Analyse der Transfers zwischen Jung und Alt in der Schweiz. I.VW HSG Schriftenreihe, Vol. 51, St. Gallen: Universität St. Gallen, Institut für Versicherungswirtschaft.

Engler, M. (2011) 'Redistribution in Switzerland: Social cohesion or simple smoothing of lifetime incomes?' Swiss Journal of Economics and Statistics 147(2): 107-155.

European Commission (2012) 'EU Sets Out Plans for Adequate, Safe and Sustainable Pensions', from www.ec. europa.eu/social/main.jsp?langId $=$ en \&catIsd $=89 \&$ newsId $=1194 \&$ furtherNews $=y e s$.

Federal Office of Statistics (Bundesamt für Statistik; BFS) (2010) Szenarien zur Bevölkerungsentwicklung der Schweiz 2010-2060, Neuchâtel: Bundesamt für Statistik.

Feld, L.P. and Schaltegger, C.A. (2011) Soziale Sicherheit sichern: Plädoyer für eine Schuldenbremse, Zürich: Avenir Suisse.

Gonand, F. and Legros, F. (2009) 'Pension reforms in France: Impact on growth and inter-generational redistributive effects', The Geneva Papers on Risk and Insurance -Issues and Practice 34(4): 639-659.

Gruber, J. and Wise, D. (eds) (2004) Social Security Programs and Retirement Around the World: Micro Estimation, Chicago: University of Chicago Press.

Hanel, B. and Riphahn, R. (2012) 'The timing of retirement-New evidence from Swiss female workers', Labour Economics 19(5): 718-728.

Kaschützke, B. (2009) 'Payout solutions for funded pension schemes: Markets, regulation and economic modelling', dissertation, Frankfurt a. M.: Universität Frankfurt.

Lindquist, G. and Wadensjö, E. (2009) 'Retirement, pensions and work in Sweden', The Geneva Papers on Risk and Insurance-Issues and Practice 34(4): 578-590.

OECD (2011) Pensions at a Glance 2011: Retirement-Income Systems in OECD and G20 Countries, Paris: OECD Publishing, from www.dx.doi.org/10.1787/pension_glance-2011-en.

OECD (2012a) OECD Health Data 2012: How Does Switzerland Compare, Paris: OECD Publishing, from www .oecd.org/switzerland/BriefingNoteSWITZERLAND2012.pdf.

OECD (2012b) 'Infrastructure investment and maintenance data 1992-2010', International Transport Forum, from www.internationaltransportforum.org/statistics/investment/data.html.

OECD (2012c) Education at a Glance 2012: OECD Indicators, Paris: OECD Publishing, from www.dx.doi.org/ 10.1787/eag-2012-en.

Sachverständigenrat zur Begutachtung der gesamtwirtschaftlichen Entwicklung (2011) Herausforderungen des demografischen Wandels, Expertise im Auftrag der Bundesregierung, Wiesbaden: Statistisches Bundesamt, Mai 2011.

Samwick, A. (1998) 'New evidence on pensions, social security, and the timing of retirement', Journal of Public Economics 70(2): 207-236.

Schön-Bühlmann, J. (2011) Freiwilligenarbeit in der Schweiz 2010, Neuchâtel: Bundesamt für Statistik.

Stock, J.H. and Wise, D. (1990) 'Pensions, the option value of work, and retirement', Econometrica 58(5): 1151-1180.

Stutz, H., Bauer, T. and Schmugge, S. (2007) Erben in der Schweiz-eine Familiensache mit volkswirtschaftlichen Folgen, Zürich: Rüegger.

Swisscanto (2012) Swisscanto Pensionskassen-Monitor per 30.06.2012, Bern/Zürich: Swisscanto Asset Management AG. 
Tremmel, J. (2003) 'Generationengerechtigkeit-Versuch einer Definition', in J. Tremmel (ed.) Handbuch Generationengerechtigkeit, München: ökom-Verlag, pp. 27-80.

World Economic Forum (2008) The Future of Pensions and Healthcare in a Rapidly Ageing World-Scenarios to 2030, Geneva: World Economic Forum.

\section{Appendix}

Table A1 Development of the number of new retirees in the BVG

\begin{tabular}{|c|c|c|c|c|c|c|c|}
\hline \multirow[t]{2}{*}{ Year } & \multicolumn{3}{|c|}{$\begin{array}{c}\text { Number of persons who reach age } \\
65 \text { (men) or } 64 \text { (women) and thus might } \\
\text { receive a pension (population at } 31 \text { December } \\
\text { of the preceding year) }\end{array}$} & \multirow[t]{2}{*}{ Growth factor } & \multicolumn{3}{|c|}{ Number of new retirees in the $B V G$} \\
\hline & Men (65) & Women (64) & Total & & Men & Women & Total \\
\hline 2010 & 41,583 & 43,938 & 85,521 & - & 29,325 & 11,390 & 40,715 \\
\hline 2011 & 42,562 & 45,935 & 88,497 & 1.03480 & 30,345 & 11,786 & 42,132 \\
\hline 2012 & 43,863 & 45,890 & 89,753 & 1.01419 & 30,776 & 11,954 & 42,730 \\
\hline 2013 & 44,113 & 46,619 & 90,732 & 1.01091 & 31,112 & 12,084 & 43,196 \\
\hline 2014 & 44,512 & 45,777 & 90,289 & 0.99512 & 30,960 & 12,025 & 42,985 \\
\hline 2015 & 44,053 & 45,871 & 89,924 & 0.99596 & 30,835 & 11,976 & 42,811 \\
\hline 2016 & 44,729 & 44,732 & 89,461 & 0.99485 & 30,676 & 11,915 & 42,591 \\
\hline 2017 & 43,434 & 46,465 & 89,899 & 1.00490 & 30,826 & 11,973 & 42,799 \\
\hline 2018 & 44,757 & 46,318 & 91,075 & 1.01308 & 31,229 & 12,130 & 43,359 \\
\hline 2019 & 44,827 & 47,515 & 92,342 & 1.01391 & 31,664 & 12,298 & 43,962 \\
\hline 2020 & 46,225 & 48,230 & 94,455 & 1.02288 & 32,388 & 12,580 & 44,968 \\
\hline 2021 & 47,676 & 49,522 & 97,198 & 1.02904 & 33,329 & 12,945 & 46,274 \\
\hline 2022 & 49,704 & 51,157 & 100,861 & 1.03769 & 34,585 & 13,433 & 48,018 \\
\hline 2023 & 50,578 & 51,816 & 102,394 & 1.01520 & 35,111 & 13,637 & 48,748 \\
\hline 2024 & 51,435 & 53,819 & 105,254 & 1.02793 & 36,091 & 14,018 & 50,110 \\
\hline 2025 & 52,724 & 55,011 & 107,735 & 1.02357 & 36,942 & 14,349 & 51,291 \\
\hline 2026 & 53,936 & 56,288 & 110,224 & 1.02310 & 37,796 & 14,680 & 52,476 \\
\hline 2027 & 55,102 & 57,576 & 112,678 & 1.02226 & 38,637 & 15,007 & 53,644 \\
\hline 2028 & 56,910 & 59,564 & 116,474 & 1.03369 & 39,939 & 15,512 & 55,451 \\
\hline 2029 & 58,713 & 60,609 & 119,322 & 1.02445 & 40,915 & 15,892 & 56,807 \\
\hline 2030 & 60,156 & 59,674 & 119,830 & 1.00426 & 41,089 & 15,959 & 57,049 \\
\hline
\end{tabular}

Note: The potential retirees, that is, the number of persons who reach age 65 (men) or 64 (women) is taken from the Federal Statistical Office. The number of new retirees in the BVG for the year 2010 are estimated based on BSV (2013). The remainder are own estimations based on this data. 
Table A2 Development of maximum and average assets at retirement entry in CHF

\begin{tabular}{lcccc}
\hline Year & Maximum assets at retirement entry in CHF & & Average assets at retirement entry in CHF \\
\cline { 2 - 3 } & Men & Women & Men & Women \\
\hline 2010 & 266,459 & 277,904 & 185,398 & 185,989 \\
2011 & 276,686 & 288,169 & 192,608 & 192,875 \\
2012 & 285,825 & 297,323 & 200,000 & 200,000 \\
2013 & 297,443 & 309,275 & 206,606 & 206,353 \\
2014 & 309,195 & 321,560 & 215,004 & 214,648 \\
2015 & 321,295 & 331,698 & 223,499 & 223,175 \\
2016 & 330,779 & 341,928 & 232,245 & 230,211 \\
2017 & 340,485 & 352,413 & 239,101 & 237,310 \\
2018 & 350,368 & 362,317 & 246,116 & 244,588 \\
2019 & 360,492 & 372,377 & 253,260 & 251,462 \\
2020 & 370,848 & 382,669 & 260,578 & 265,586 \\
2021 & 381,370 & 393,156 & 268,064 & 265,586 \\
2022 & 392,105 & 403,944 & 275,670 & 272,865 \\
2023 & 402,834 & 414,917 & 283,429 & 280,352 \\
2024 & 413,669 & 426,162 & 291,185 & 287,968 \\
2025 & 424,810 & 425,274 & 299,017 & 295,772 \\
2026 & 427,857 & 423,984 & 307,070 & 295,156 \\
2027 & 430,807 & 422,703 & 309,273 & 294,260 \\
2028 & 433,795 & 425,483 & 311,405 & 293,371 \\
2029 & 436,707 & 428,339 & 313,565 & 295,301 \\
2030 & 439,664 & 430,805 & 315,670 & 297,283 \\
\hline
\end{tabular}

Note: The maximum assets at retirement in 2010, 2011 and 2012 are taken from BSV (2011). The average assets at retirement for the year 2012 are taken from EDI (2011). The remainder are own estimations based on this data. 
Table A3 Development of the number of new retirees in the BVG according to different demographic scenarios

\begin{tabular}{|c|c|c|c|c|c|c|c|c|c|}
\hline \multirow[t]{2}{*}{ Year } & \multicolumn{3}{|c|}{ Low } & \multicolumn{3}{|c|}{ Middle } & \multicolumn{3}{|c|}{ High } \\
\hline & Men & Women & Total & Men & Women & Total & Men & Women & Total \\
\hline 2010 & 29,325 & 11,390 & 40,715 & 29,325 & 11,390 & 40,715 & 29,325 & 11,390 & 40,715 \\
\hline 2011 & 30,314 & 11,774 & 42,088 & 30,345 & 11,786 & 42,132 & 30,375 & 11,798 & 42,173 \\
\hline 2012 & 30,707 & 11,927 & 42,633 & 30,776 & 11,954 & 42,730 & 30,841 & 11,979 & 42,820 \\
\hline 2013 & 30,999 & 12,040 & 43,039 & 31,112 & 12,084 & 43,196 & 31,214 & 12,124 & 43,338 \\
\hline 2014 & 30,799 & 11,963 & 42,762 & 30,960 & 12,025 & 42,985 & 31,107 & 12,082 & 43,190 \\
\hline 2015 & 30,616 & 11,892 & 42,508 & 30,835 & 11,976 & 42,811 & 31,025 & 12,050 & 43,076 \\
\hline 2016 & 30,399 & 11,807 & 42,207 & 30,676 & 11,915 & 42,591 & 30,918 & 12,009 & 42,927 \\
\hline 2017 & 30,488 & 11,842 & 42,330 & 30,826 & 11,973 & 42,799 & 31,115 & 12,085 & 43,201 \\
\hline 2018 & 30,816 & 11,969 & 42,785 & 31,229 & 12,130 & 43,359 & 31,581 & 12,266 & 43,847 \\
\hline 2019 & 31,176 & 12,109 & 43,285 & 31,664 & 12,298 & 43,962 & 32,079 & 12,460 & 44,538 \\
\hline 2020 & 31,807 & 12,354 & 44,161 & 32,388 & 12,580 & 44,968 & 32,880 & 12,771 & 45,651 \\
\hline 2021 & 32,650 & 12,681 & 45,331 & 33,329 & 12,945 & 46,274 & 33,905 & 13,169 & 47,074 \\
\hline 2022 & 33,800 & 13,128 & 46,928 & 34,585 & 13,433 & 48,018 & 35,256 & 13,694 & 48,950 \\
\hline 2023 & 34,223 & 13,292 & 47,515 & 35,111 & 13,637 & 48,748 & 35,874 & 13,934 & 49,808 \\
\hline 2024 & 35,072 & 13,622 & 48,694 & 36,091 & 14,018 & 50,110 & 36,961 & 14,356 & 51,317 \\
\hline 2025 & 35,790 & 13,901 & 49,691 & 36,942 & 14,349 & 51,291 & 37,933 & 14,734 & 52,667 \\
\hline 2026 & 36,504 & 14,178 & 50,682 & 37,796 & 14,680 & 52,476 & 38,914 & 15,114 & 54,028 \\
\hline 2027 & 37,203 & 14,450 & 51,653 & 38,637 & 15,007 & 53,644 & 39,878 & 15,489 & 55,367 \\
\hline 2028 & 38,335 & 14,890 & 53,225 & 39,939 & 15,512 & 55,451 & 41,328 & 16,052 & 57,380 \\
\hline 2029 & 39,135 & 15,200 & 54,336 & 40,915 & 15,892 & 56,807 & 42,462 & 16,493 & 58,955 \\
\hline 2030 & 39,141 & 15,203 & 54,344 & 41,089 & 15,959 & 57,049 & 42,792 & 16,621 & 59,412 \\
\hline
\end{tabular}

Note: The "middle" scenario corresponds to the result in Table A1. The "low" and "high" scenarios are identical projections with different demographic scenarios for the number of persons who reach age 65 (men) or 64 (women) as input numbers. The demographic scenarios are taken from the Federal Statistical Office.

\section{About the Author}

Martin Eling is Professor for Insurance Management and Director of the Institute of Insurance Economics at the University of St. Gallen. He received his doctoral degree in 2005 from the University of Münster and his Habilitation in 2009 from the University of St. Gallen. From 2009 to 2011 he was Director of the Institute of Insurance Science at the University of Ulm. His main research interests are asset management, risk management, regulation and empirical aspects of finance and insurance. 